\title{
Stable isotopes in precipitation in the Asian monsoon region
}

\author{
M. Vuille \\ Climate System Research Center, Department of Geosciences, University of Massachusetts, Amherst, Massachusetts, USA
}

M. Werner

Max-Planck-Institute for Biogeochemistry, Jena, Germany

R. S. Bradley and F. Keimig

Climate System Research Center, Department of Geosciences, University of Massachusetts, Amherst, Massachusetts, USA

Received 25 March 2005; revised 25 July 2005; accepted 28 September 2005; published 8 December 2005.

[1] The influence of the Asian monsoon on the $\delta^{18} \mathrm{O}$ composition of precipitation is investigated on the basis of the ECHAM-4 Atmospheric General Circulation Model (AGCM), fitted with stable isotopic tracers. The model is forced with prescribed sea surface temperatures (SST) over the last few decades of the 20th century. The simulated climate and climate-stable isotope relationships are validated with observational data from the International Atomic Energy Agency-Global Network of Isotopes in Precipitation (IAEA-GNIP) and reanalysis data. The model shows deficiencies when simulating interannual variations of monsoon precipitation, but the associated monsoon circulation is quite accurately reproduced, in particular when run in a high-resolution (T106) version. The modeled stable isotope distribution is quite similar to observations, but the local climatic controls on $\delta^{18} \mathrm{O}$ are overestimated. The influence of the Asian monsoon on $\delta^{18} \mathrm{O}$ is analyzed on the basis of a vertical wind shear index $M$, indicative of variations in large-scale monsoon strength. The ECHAM model simulates a significant negative relationship between $\delta^{18} \mathrm{O}$ composition of precipitation and $M$ over most monsoon-affected areas, consistent with the IAEA-GNIP data. Variations in the amount of precipitation provide a first-order explanation for this relationship. Distillation processes during transport and hence increased rainout and depletion of heavy isotopes upstream may also lead to a significant monsoon- $\delta^{18} \mathrm{O}$ relationship in areas where local precipitation is not affected by monsoon variability. The modern $\delta^{18} \mathrm{O}$ record from the Dasuopu ice core in the Himalayas is a good indicator of the large-scale monsoon circulation, a relationship that is correctly simulated by the T106 version of the ECHAM model. Our results suggest that $\delta^{18} \mathrm{O}$ variations in this region are sensitive to fluctuations in Asian monsoon intensity.

Citation: Vuille, M., M. Werner, R. S. Bradley, and F. Keimig (2005), Stable isotopes in precipitation in the Asian monsoon region, J. Geophys. Res., 110, D23108, doi:10.1029/2005JD006022.

\section{Introduction}

[2] Variations in the strength, timing and duration of the Asian summer monsoon affect the lives of millions of people. The summer precipitation maximum between June and September associated with the Asian summer monsoon extends from southeast Asia to India and the Arabian Peninsula. Significant departures from the normal rainfall amount during this season can cause large-scale flooding or drought and thereby seriously affect regional economies and agricultural production. Hence enormous efforts are under way to better understand the causes and consequences of interannual to interdecadal monsoon variability. Recent studies have focused on the influence of Eurasian snow cover and soil wetness [e.g., Meehl, 1994; Bamzai and

Copyright 2005 by the American Geophysical Union. 0148-0227/05/2005JD006022\$09.00
Shukla, 1999; Robock et al., 2003], the ENSO-monsoon relationship [e.g., Webster and Yang, 1992; Ju and Slingo, 1995; Kumar et al., 1999; Lau and Wu, 2001], and Indian Ocean SST [e.g. Oelfke Clark et al., 2000; Wu and Kirtman, 2004]. A common goal of these studies is to improve upon current prediction schemes for the Asian monsoon, which would allow for better adaptation and mitigation strategies well in advance of the monsoon season [e.g., Webster et al., 1998; Goswami, 2004].

[3] Most of these studies focus on the most recent time period extending back only a few decades, and therefore do not include the full envelope of natural monsoon variability. Studies focusing on paleomonsoon intensity over the past centuries to millennia have helped to broaden our understanding of past changes in the Asian monsoon domain. They indicate that in the past monsoon changes did not always occur as a gradual transition due to slow changes in orbital forcing, but were sometimes very abrupt [e.g., 
Overpeck et al., 1996; Gupta et al., 2003; Morrill et al., 2003]. This is an important finding given the prospects of future climate change impacts on the Asian monsoon [e.g., Meehl and Washington, 1993]. Many of these paleomonsoon records are based on stable isotopes from meteoric waters incorporated into ice cores on the Tibetan Plateau and the Himalayas [e.g., Thompson et al., 1997, 2000; Kang et al., 2000; Tian et al., 2003; Davis and Thompson, 2004; Duan et al., 2004; Davis et al., 2005], speleothems from the Arabian Peninsula, India and China, [Wang et al., 2001a; Burns et al., 2002; Fleitmann et al., 2003; Yuan et al., 2004; Yadava and Ramesh, 2005] and tree ring cellulose from China [e.g., Feng et al., 1999]. Yet these records are often difficult to compare as they are derived from different proxies, often located far apart in very different environmental settings, and recording monsoon variability in varying temporal resolution. In addition the interpretation of the stable isotopic composition $\left(\delta^{18} \mathrm{O}, \delta \mathrm{D}\right)$ is not always straightforward, and the knowledge of modern climatic controls, on which such an interpretation could be based, is often inadequate.

[4] To address some of these questions we present a study on interannual variability of stable isotopes $\left(\delta^{18} \mathrm{O}\right)$ in precipitation in the Asian monsoon region and how this variability relates to both local climatic controls and the large-scale monsoon circulation. A number of observational studies have addressed these questions on various regional scales over India [Bhattacharya et al., 2003], China [e.g., Johnson and Ingram, 2004], the Himalayas and the Tibetan Plateau [e.g., Tian et al., 2001, 2003; Kang et al., 2002] and southeast Asia [e.g., Araguas-Araguas et al., 1998; Aggarwal et al., 2004]. A comprehensive study, linking stable isotopic variations throughout the region with interannual fluctuations of monsoon strength, however, has been missing. Besides observational data we also employ two different versions of the ECHAM-4 Atmospheric General Circulation Model (AGCM), fitted with isotopic tracers. Hoffmann and Heimann [1997] presented a similar study of the Asian monsoon signal in stable water isotopes based on an earlier version of the ECHAM model, but they focused only on mean conditions for present day and the Last Glacial Maximum and did not attempt to simulate interannual variability.

[5] In the next section we present the data and methods that were used. Section 3 entails a model evaluation for variables relevant to the study of the Asian monsoon-stable isotope relationship. In section 4 we discuss both local climatic and large-scale monsoon controls on the stable isotopic composition of precipitation. In section 5 we compare model results with observational evidence from an ice core record in the Himalayas. Section 6 ends with a summary and some concluding remarks.

\section{Data and Methods}

[6] To study the spatial distribution of stable isotopes in precipitation over the Asian monsoon region we extracted monthly means of $\delta^{18} \mathrm{O}$ in precipitation from the IAEAGNIP database [International Atomic Energy Agency/World Meteorological Organization, 2004], including all stations in the domain $\left(0^{\circ}-160^{\circ} \mathrm{E}, 40^{\circ} \mathrm{N}-40^{\circ} \mathrm{S}\right)$ with a record length of at least 24 months. Many of these records are short, contain significant data gaps and cover varying time periods, which do not always overlap with one another. This limitation clearly makes an interpretation more difficult and shows that caution should be exercised when comparing these records with each other or with model output. Nonetheless, the IAEA data are a unique data source to study monsoon-related isotopic variations and provides a useful database for evaluation of stable isotope models in this region.

[7] In addition to this observational data set we employ two different simulations from the ECHAM-4 stable isotope model [Hoffmann et al., 1998; Werner et al., 2001]. This model is based on a hybrid sigma-pressure coordinate system and was run with triangular truncation at both wave number 30 (T30 $\sim 3.75^{\circ}$ lat. $\times 3.75^{\circ}$ long) and $106(\mathrm{~T} 106$ $\sim 1.1^{\circ}$ lat. $\times 1.1^{\circ}$ lon.), including 19 vertical layers from surface to $30 \mathrm{hPa}$. While ECHAM-4 T106 (1979-1998) covers essentially the last 2 decades of the 20th century, the ECHAM-4 T30 simulation is considerably longer, covering the period 1903-1994. Here however, we limit our analysis to the period 1950-1994, for which the model performance can be compared to reanalysis and IAEA-GNIP stable isotope data. Both experiments are run under modern boundary conditions with prescribed, monthly, global sea surface temperature (SST) fields based on GISST 2.2 (Global Sea-Ice and Sea Surface Temperature) data. Another minor difference between the models is associated with the greenhouse gas concentrations: These were kept at a constant modern level in the ECHAM-4 T106 simulation, but adjusted annually in the ECHAM-4 T30 experiment. Further details on model setup and model performance in the tropics are given by Vuille et al. [2003a, 2003b], who analyzed data from the same simulations over the tropical Americas.

[8] Reanalysis data from the National Centers for Environmental Prediction-National Center for Atmospheric Research (NCEP-NCAR) [Kalnay et al., 1996], available since 1948 on a $2.5^{\circ} \times 2.5^{\circ}$ horizontal grid with 17 vertical pressure levels, were used to describe variations in the large-scale circulation associated with the Asian monsoon. Monsoon precipitation and convective activity were assessed on the basis of Climate Prediction Center (CPC) Merged Analysis of Precipitation (CMAP) [Xie and Arkin, 1997] data, available since 1979, and NOAA interpolated Outgoing Longwave Radiation (OLR) data [Liebmann and Smith, 1996], available since 1974.

\section{Model Evaluation}

[9] An in-depth analysis of the performance of the ECHAM-4 stable isotope AGCM in the tropics has been provided by Vuille et al. [2003a] for the tropical Americas. Although their results are not directly applicable to the Asian monsoon region, many aspects of the tropical climate are similar. In addition a number of studies provide detailed analyses on the performance of the ECHAM-4 model in the Asian monsoon region [Cherchi and Navarra, 2003; Tschuck et al., 2004] and the tropics in general [e.g., Moron et al., 1998]. Hence here we focus on a few selected variables only, which are of particular relevance for our study. These variables include precipitation (section 3.1.), stable isotopic composition $\left(\delta^{18} \mathrm{O}\right)$ of precipitation (section 
a) CMAP

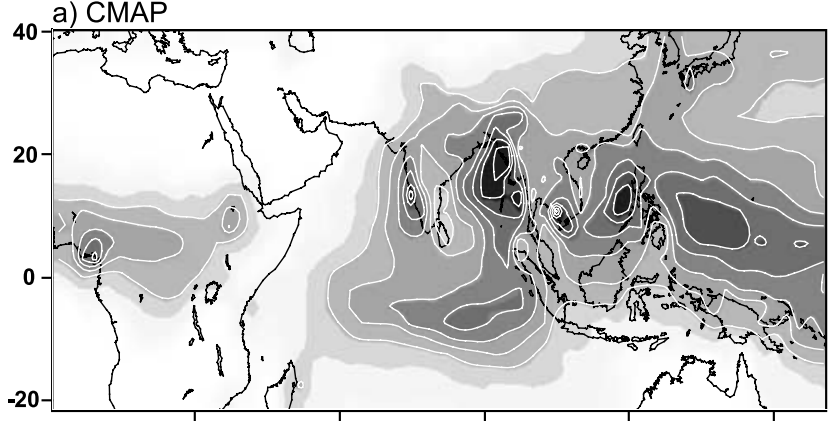

b) ECHAM-4 T106

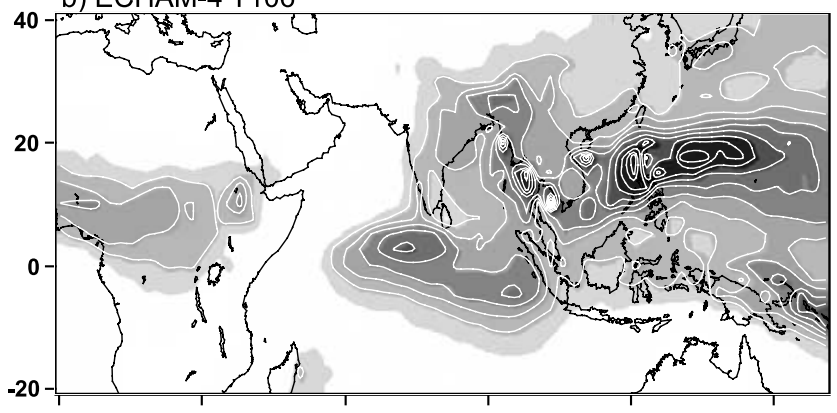

c) ECHAM-4 T30
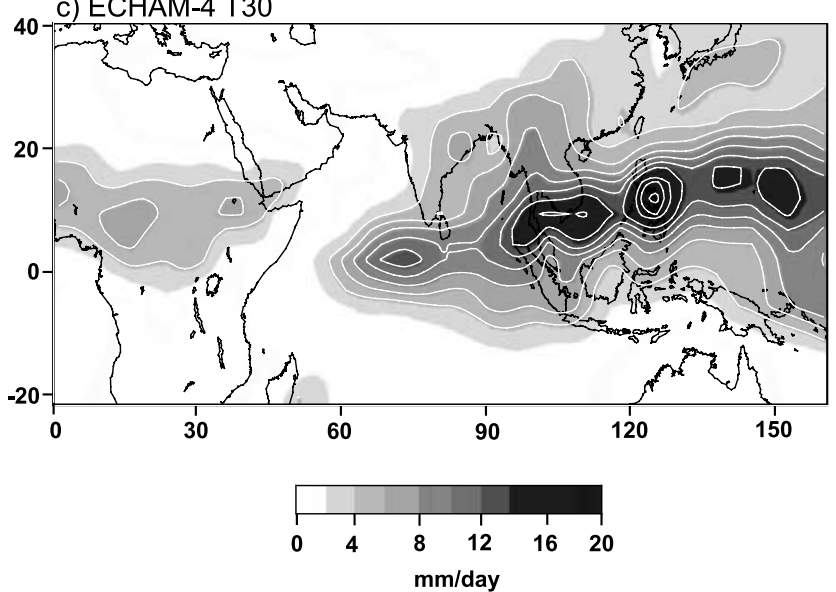

Figure 1. JJAS precipitation (in $\mathrm{mm} \mathrm{d}^{-1}$ ) for (a) CMAP, (b) ECHAM-4 T106, and (c) ECHAM-4 T30. All plots are averaged over time period 1980-1994.

3.2.) and the upper and lower tropospheric monsoon circulation (section 3.3.).

\subsection{Precipitation}

[10] To analyze the spatial pattern of precipitation at the height of the Asian summer monsoon, we show the average monsoon precipitation during boreal summer (JJAS) in Figure 1. The CMAP data (Figure 1a) show regional precipitation maxima over tropical Africa north of the equator, along the west coast of India (the western Ghats), in the Bay of Bengal and over southeast Asia and the western tropical Pacific. An additional precipitation maximum is located over the Indian Ocean, south of the equator. The ECHAM-T106 model quite accurately reproduces the large-scale precipitation field over the Indian Ocean, and correctly positions the precipitation maxima over the western Pacific, southeast Asia, equatorial Africa and the southern Indian Ocean (Figure 1b). The ECHAM-T30 simulation is less realistic and does not show the two separate precipitation maxima over the Bay of Bengal and the southern Indian Ocean and also fails to simulate the precipitation maxima over the western Ghats (Figure 1c), a deficiency already noted by Cherchi and Navarra [2003]. This deficiency in producing an accurate representation of Asian monsoon precipitation is not unique to the ECHAM model, but includes all models participating in AMIP comparisons [e.g., Sperber and Palmer, 1996; Gadgil and Sajani, 1998; Moron et al., 1998; Cherchi and Navarra, 2003].

[11] Since we will primarily focus on interannual monsoon variability in the remainder of this study, it is necessary to also assess the skill of the model in simulating interannual rainfall variations. Figure 2 shows the standardized anomalies of monsoon precipitation, area-averaged over the domain $40^{\circ} \mathrm{N}-20^{\circ} \mathrm{S}, 45^{\circ} \mathrm{E}-160^{\circ} \mathrm{E}$ for each summer (JJAS) between 1980 and 1994. CMAP precipitation, plotted over the same domain as a reference, clearly demonstrates the well-known biennial tendency of the Asian monsoon, with rainfall that is increased in one year and reduced in the next [e.g., Webster et al., 1998]. Only the higher-resolution ECHAM simulation (T106) agrees with CMAP observations $(\mathrm{r}=0.65, \mathrm{p}<0.01)$, while the T30 simulation $(\mathrm{r}=$ 0.26 ) is not significantly correlated with CMAP. The fact that the higher resolution appears to improve the simulation of precipitation variability may be related to a better ability of the model to simulate tropical synoptic-scale activity [Jha et al., 2000].

\subsection{Stable Isotope Distribution}

[12] Figure 3 shows a comparison of the annual mean precipitation-weighted $\delta^{18} \mathrm{O}$ values based on the IAEA network with the corresponding model fields. Both simulations generally capture the main features associated with the spatial $\delta^{18} \mathrm{O}$ distribution. The most depleted values occur in the northern midlatitudes, including the higher elevations of the Himalayas and Tibet. This depletion is due to a combination of factors. Within the monsoon belt it is the result of the gradual rainout of moist oceanic air

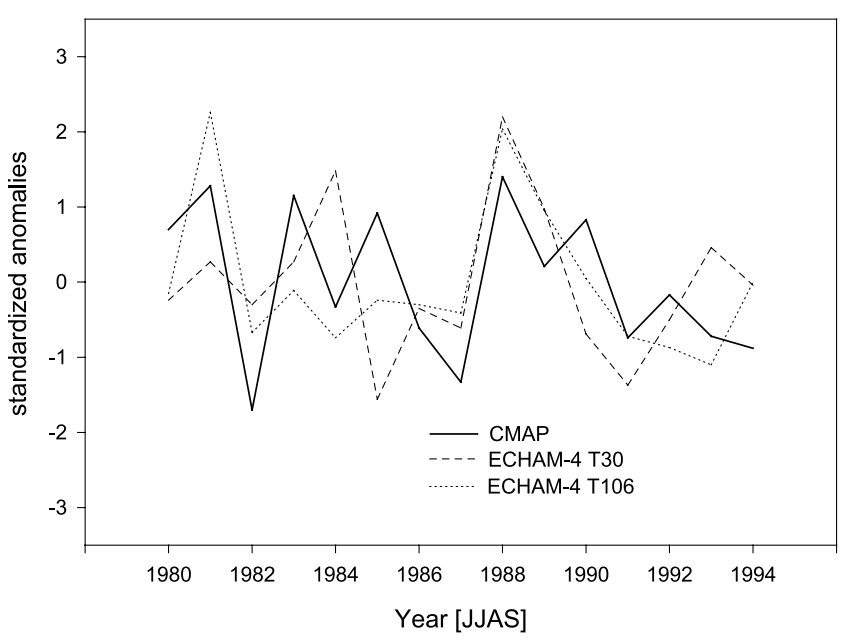

Figure 2. Time series of standardized summer (JJAS) precipitation anomalies averaged over the Asian monsoon domain $\left(40^{\circ} \mathrm{N}-20^{\circ} \mathrm{S}, 45^{\circ} \mathrm{E}-160^{\circ} \mathrm{E}\right)$ between 1980 and 1994. 
a) IAEA

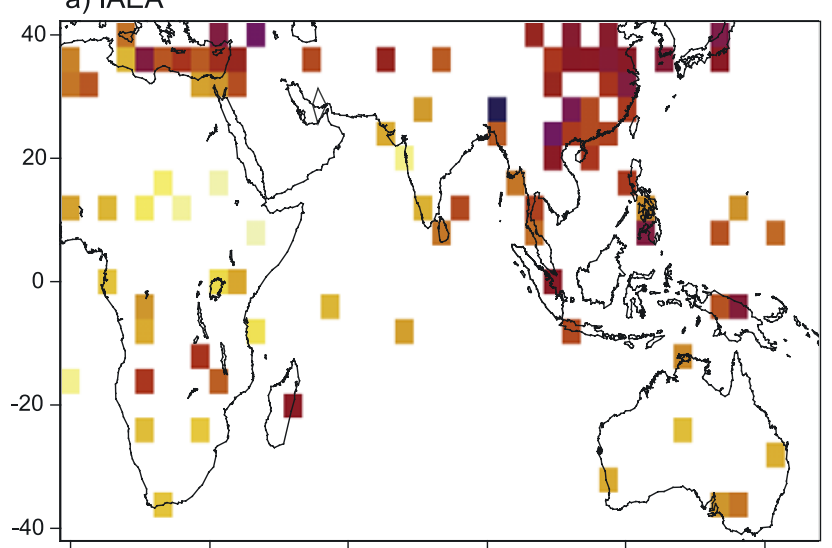

b) ECHAM-4 T106

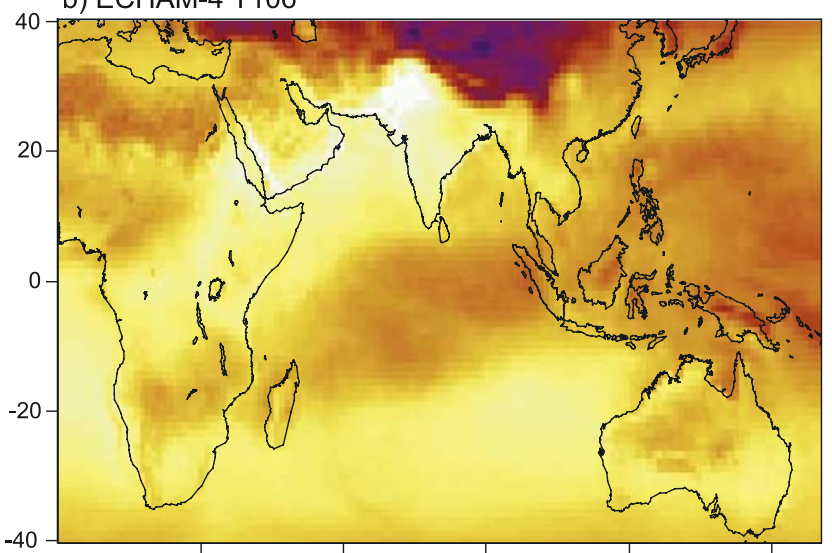

c) ECHAM-4 T30

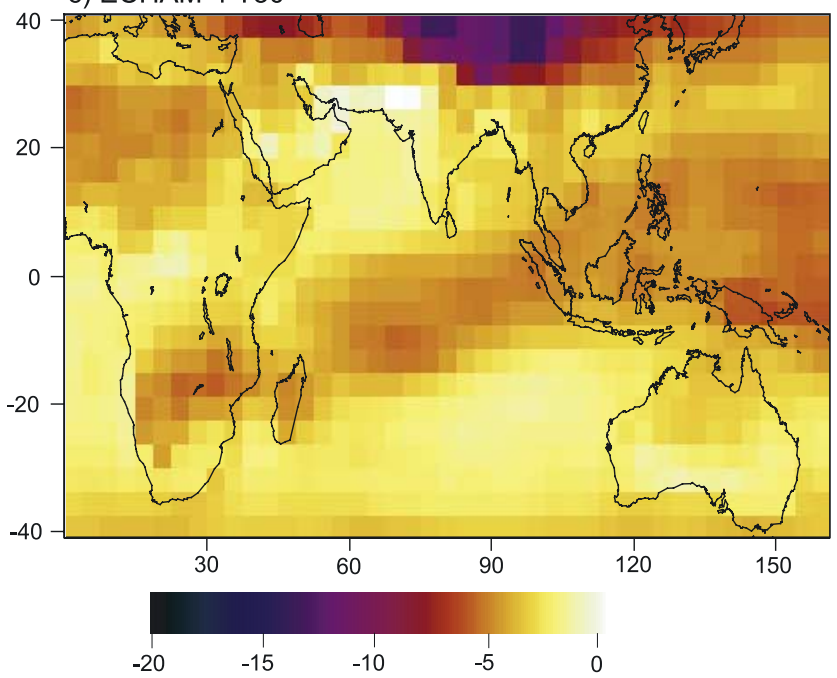

Figure 3. (a) Annual mean precipitation-weighted $\delta^{18} \mathrm{O}$ (in permil) based on IAEA station data. (b) As in Figure 3a but for ECHAM-4 T106. (c) As in Figure 3a but for ECHAM-4 T30.

masses moving inland [e.g., Araguas-Araguas et al., 1998], while further north cold winter temperatures are the main climatic control. This interplay is most discernible on seasonal timescales and is discussed in more detail below (Figure 4). The main centers of convective activity in the Indian Ocean, southeast Asia and the western equatorial
Pacific are equally characterized by more depleted $\delta^{18} \mathrm{O}$ values due to more intense vertical uplift and distillation. Conversely the most enriched values, simulated over the southern Indian Ocean and the dry zones of the Arabian Sea, and the Arabian Peninsula are more difficult to verify,

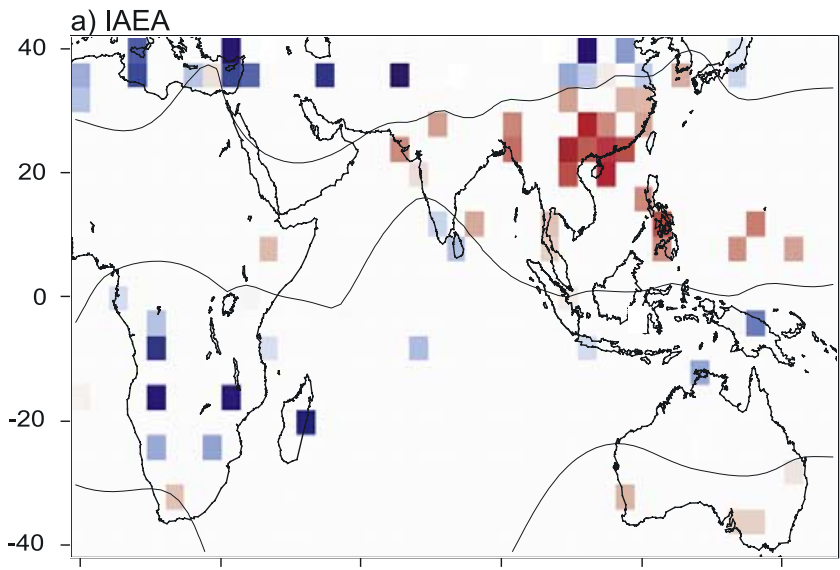

\section{b) ECHAM-4 T106}

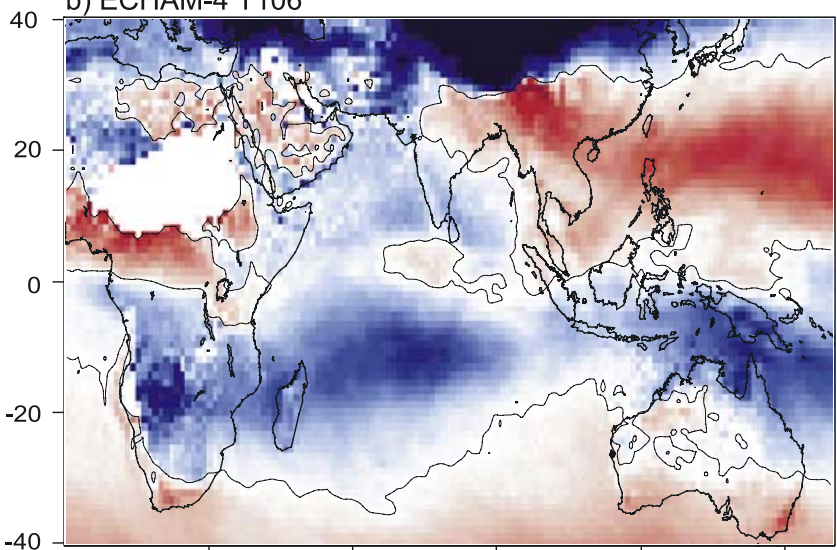

c) ECHAM-4 T30

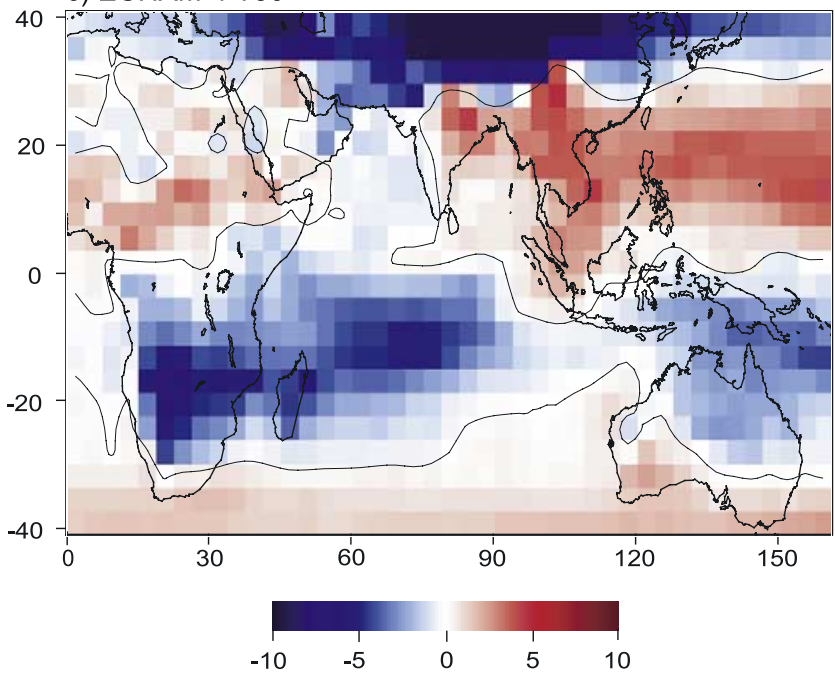

Figure 4. (a) DJF-JJA $\delta^{18} \mathrm{O}$ (in permil) based on IAEA station data. (b) As in Figure 4a but for ECHAM-4 T106. (c) As in Figure 4a but for ECHAM-4 T30. Black lines indicate interpolated 0-contour. White areas in Figure $4 \mathrm{~b}$ represent regions where no precipitation occurred in either DJF or JJA. 
Table 1. Correlation Coefficient $(r)$, Bias $(b)$ and Root Mean Square Error (RMSE) Calculated Between Precipitation-Weighted Annual Mean $\delta^{18} \mathrm{O}$ From IAEA Network and Corresponding Grid Cell Values in Models ${ }^{\mathrm{a}}$

\begin{tabular}{lccc}
\hline \multicolumn{1}{c}{ Simulation } & $r$ & $\mathrm{~b}$ & $R M S E$ \\
\hline ECHAM-4 T30 & 0.52 & 0.85 & 2.5 \\
ECHAM-4 T106 & 0.66 & 0.99 & 2.2 \\
\hline
\end{tabular}

${ }^{\mathrm{a}}$ Units for $b$ and $R M S E$ are in permil.

because of the lack of observations. The most apparent differences between the model and observations occur over the African continent. Both ECHAM simulations show values that are too depleted over the Sahara and too enriched in the tropics. In fact the north-south gradient with more depleted values over the Sahara and more enriched values in the tropics is exactly the opposite of what the few available observations suggest.

[13] A more quantitative analysis of the model performance is shown in Table 1. The correlation coefficient $(r)$, bias (b), and root mean square error (RMSE) are calculated by comparing the precipitation-weighted annual mean $\delta^{18} \mathrm{O}$ value from the IAEA data with the corresponding grid cell data in the models. The bias $b$ is defined as the mean difference between model and observations, while the root mean square error (RMSE) is calculated as:

$$
R M S E=\left[\frac{1}{N} \sum_{i=1}^{N}\left(\operatorname{sim} \delta^{18} O_{i}-o b s \delta^{18} O_{i}\right)^{2}\right]^{1 / 2}
$$

where $N=131$ is the number of observations, $o b s \delta^{18} O_{i}$ is the observed value at location $i$ and $\operatorname{sim} \delta^{18} O_{i}$ is the corresponding grid cell value simulated by the model. The ECHAM model is positively biased, with $\delta^{18} \mathrm{O}$ values that are on average $\sim 0.9$ permil too enriched when compared with observations. This is most obvious over some of the land areas, such as southern China and equatorial Africa and is a model deficiency that has also been noted over the Amazon basin [Vuille et al., 2003a]. The higher-resolution version (T106) performs better when the mean error and the correlation coefficient are considered. The T106 simulation in general corresponds more closely with observations as the higher resolution of the model allows an improved simulation of stable isotope variations associated with topographic features, which are not discernible in T30 resolution. The statistics in Table 1, however, should be interpreted with some caution, as the spatial distribution of the IAEA data is very uneven; hence the results are spatially biased toward regions with dense station coverage. In addition the comparison is based on different time periods, and although the overall spatial pattern of observations is considered to be robust, individual data points with very short records may be influenced by interannual to decadal variations of $\delta^{18} \mathrm{O}$.

[14] The seasonal cycle of $\delta^{18} \mathrm{O}$ is illustrated in Figure 4 by comparing the difference in the stable isotopic composition between boreal summer and winter (DJF-JJA). In much of the tropics, on the seasonal timescale, $\delta^{18} \mathrm{O}$ is more depleted during the rainy season, while in middle and higher latitudes the dominant control on seasonal timescales is temperature and therefore $\delta^{18} \mathrm{O}$ is more negative during the respective winter season. This rapid transition from precipitation- to temperature-controlled $\delta^{18} \mathrm{O}$ occurs at approximately $30^{\circ} \mathrm{S}$ and $30^{\circ} \mathrm{N}$, apparent in particular over interior China, Australia, and southern Africa. The 0-contour line separating regions with more depleted $\delta^{18} \mathrm{O}$ during the wet season from regions where $\delta^{18} \mathrm{O}$ is more negative during the winter closely tracks the poleward extent of the summer monsoon precipitation [e.g., Araguas-Araguas et al., 1998; Tian et al., 2001, 2003; Johnson and Ingram, 2004] and is correctly simulated by the model. The transition zone near the equator occurs because $\delta^{18} \mathrm{O}$ is more depleted during the respective rainy season, which is in DJF to the south and JJA to the north of the equator. This differentiation is very clear over east Asia, but because of the lack of observations it is more difficult to confirm over the Indian Ocean, and the arid regions of northern Africa, the Arabian Peninsula and the Arabian Sea.

\subsection{Large-Scale Monsoon Circulation}

[15] Variations in the strength of the Asian monsoon are often characterized in terms of droughts or floods. While these events have an immediate impact on local societies and economies, precipitation anomalies are not spatially homogeneous and long and reliable records from many monsoon regions are lacking. The often-used All India rainfall index for example, may provide a good measure of monsoon strength over India, but not elsewhere. Since we are trying to assess the impact of monsoon strength on the stable isotopic composition of precipitation, the entire transport history and hence the atmospheric circulation is of importance. For our purpose, it therefore makes more sense to characterize the monsoon intensity in terms of the largescale circulation. In addition AGCMs, including the ECHAM-4 model, generally show a better ability to simulate large-scale fluctuations of the monsoon flow than regional-scale rainfall variations [Sperber and Palmer, 1996; Cherchi and Navarra, 2003].

[16] Figure 5 shows both the upper and the lower level wind field at the height of the Asian monsoon averaged between June and September (JJAS) for both reanalysis data and AGCM simulations. At the $850 \mathrm{hPa}$ level (Figure 5b) the monsoon is characterized by a strong southerly crossequatorial flow (Somali jet) over the western Indian Ocean near the coast of East Africa. This flow feeds into the southwesterly monsoon that is established during the summer months over the Arabian Sea and the Indian subcontinent as a result of the land-sea temperature contrast. The frequent cyclones that develop in the Bay of Bengal during the monsoon season on synoptic timescales are apparent in the summer mean flow as the characteristic monsoon trough to the east of the Indian subcontinent. At the $250 \mathrm{hPa}$ level (Figure 5a) the subtropical westerly jet is displaced poleward during boreal summer and an upper tropospheric anticyclonic circulation is established over the Tibetan Plateau with an associated monsoonal easterly return flow over the northern and equatorial Indian Ocean.

[17] These main monsoon features are reproduced reasonably well in both versions of the ECHAM model. In T30 resolution the upper level easterlies are too weak and they do not extend westward all the way across the equatorial Indian Ocean (Figure 5e). This discrepancy in the wind field has implications for the accurate simulation of the stable 
a) NCEP-NCAR, $250 \mathrm{hPa}$

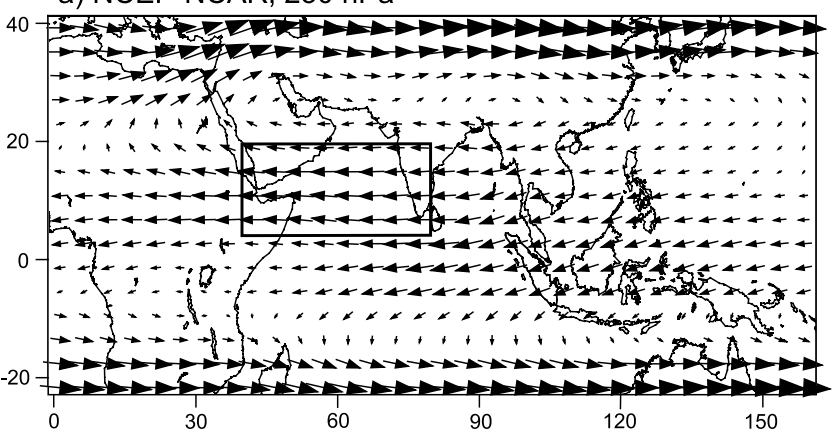

c) ECHAM-4 T106, $250 \mathrm{hPa}$

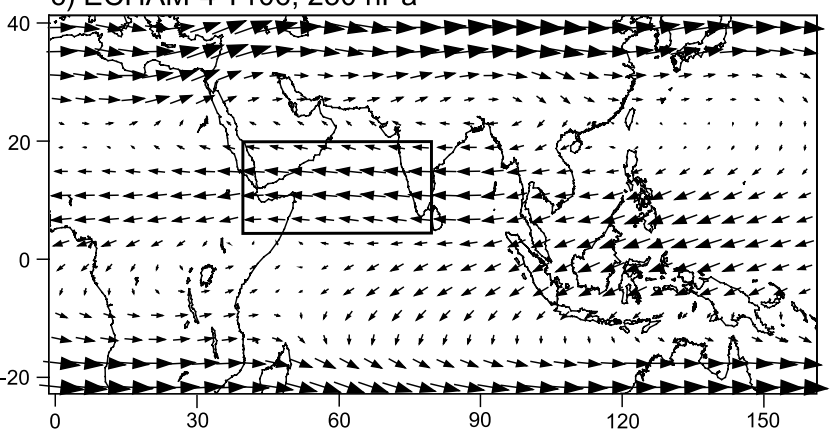

e) ECHAM-4 T30, $250 \mathrm{hPa}$

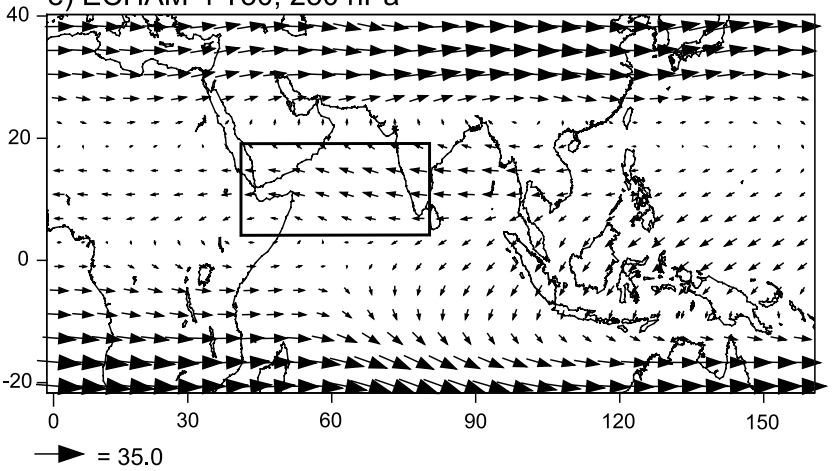

b) NCEP-NCAR, $850 \mathrm{hPa}$

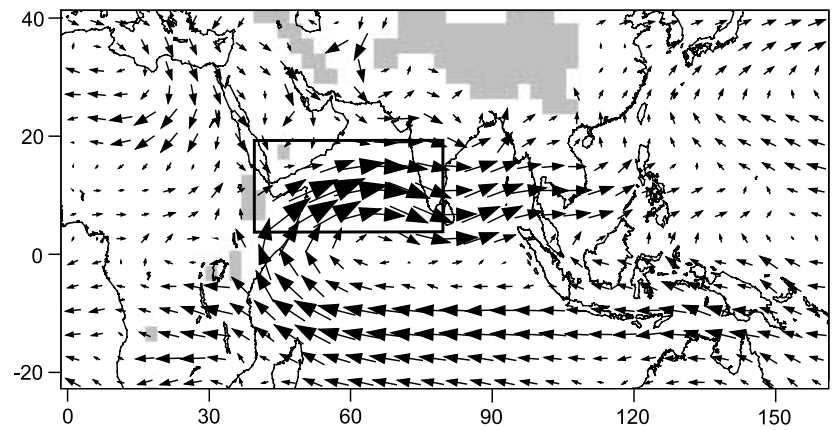

d) ECHAM-4 T106, $850 \mathrm{hPa}$

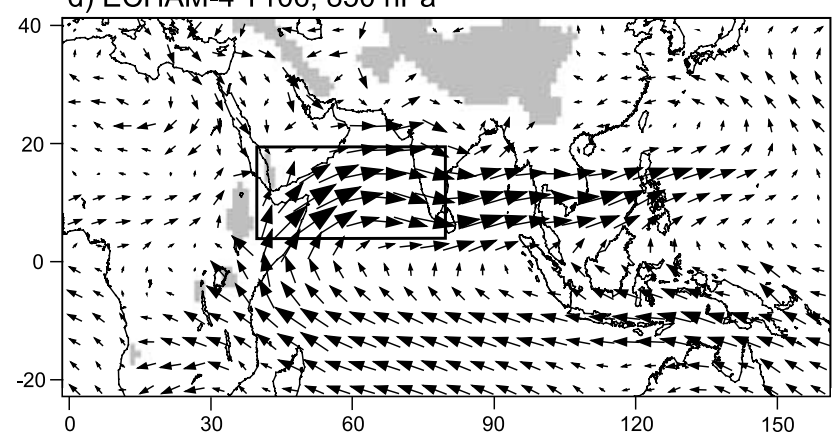

f) ECHAM-4 T30, $850 \mathrm{hPa}$

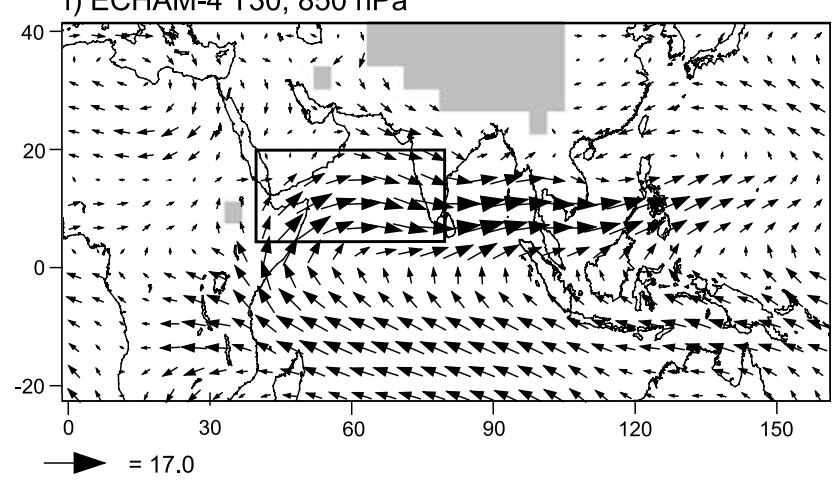

Figure 5. (a) NCEP-NCAR JJAS $250 \mathrm{hPa}$ wind, (b) as in Figure 5a but for $850 \mathrm{hPa}$, (c) as in Figure 5a but for ECHAM-4 T106, (d) as in Figure 5c but for $850 \mathrm{hPa},(\mathrm{e})$ as in Figure 5a but for ECHAM-4 T30, and (f) as in Figure 5e but for $850 \mathrm{hPa}$. Figures 5a-5f show average between 1980 and 1994 and have been resampled onto a $2.5^{\circ}$ lat. $\times 2.5^{\circ}$ lon. grid for easier comparison. Scale for wind vector (in $\mathrm{m} \mathrm{s}^{-1}$ ) is the same in all plots for each level and shown below. Solid box indicates region used for monsoon index $M\left(5-20^{\circ} \mathrm{N} ; 40-80^{\circ} \mathrm{E}\right)$. Shading in Figures $5 \mathrm{~b}, 5 \mathrm{~d}$, and $5 \mathrm{f}$ indicates model topography $>1500 \mathrm{~m}$.

isotopic tracers in the model, which are discussed further in section 5 . In both simulations the low-level westerly monsoon flow extends farther east into the western Pacific than is suggested by the reanalysis data (Figures $5 \mathrm{~d}$ and $5 \mathrm{f}$ ). Finally, both models show an unrealistic cross-equatorial flow over the entire Indian Ocean, while this strong meridional flow is funneled into the Somali jet in the reanalysis data. Nonetheless the disagreements between simulations and observations are relatively minor compared to the precipitation fields, where much larger model deficiencies are apparent (Figure 1).

[18] As shown by Webster and Yang [1992] the vertical shear between upper and lower tropospheric zonal flow, apparent in the wind field over the Asian monsoon domain during boreal summer (Figure 5), is a good measure of monsoon intensity. During strong monsoon seasons both the upper air easterlies and the low-level westerlies speed up, while a relaxation can be observed during weak monsoon years [e.g., Webster and Yang, 1992; Ju and Slingo, 1995]. This relationship between the strength of convective activity and associated latent heat release over south Asia and the magnitude of the vertical shear in the region can be explained by interpreting the monsoon flow as a lowestorder baroclinic Rossby wave response to monsoon heating [Gill, 1980]. Hence we define interannual monsoon variability as the difference between the upper and lower 

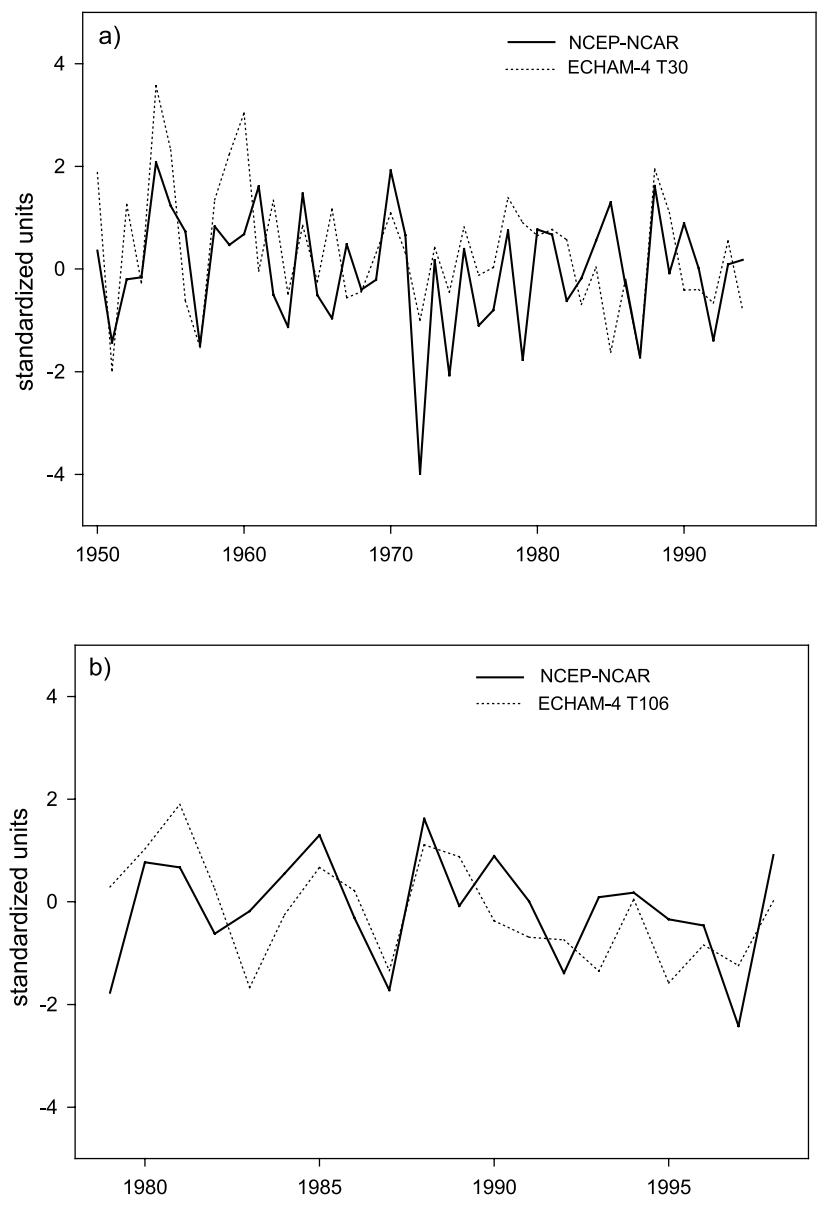

Figure 6. (a) Time series of interannual variations of monsoon index $M$ in JJAS for NCEP-NCAR and ECHAM4 T30 between 1950 and 1994. (b) As in Figure 6a but for NCEP-NCAR and ECHAM-4 T106 between 1979 and 1998.

level zonal wind velocity anomalies during boreal summer [Webster and Yang, 1992]:

$$
M=u_{850}-u_{250}
$$

with $M$ being an index of monsoon intensity and $u_{850}$ and $u_{250}$ being the domain- and time-averaged zonal wind anomalies in JJAS at 850 and $250 \mathrm{hPa}$, respectively.

[19] There has been considerable debate as to which domain best represents this monsoon flow [Webster and Yang, 1992; Goswami et al., 1999; Wang and Fan, 1999; Goswami, 2000; Wang et al., 2001b]. Wang and Fan [1999] recommended using two separate subdomains to characterize either the monsoon over India and interior Asia or the monsoon over southeast Asia. As we are interested in the monsoon signal derived from the stable isotopic composition of ice cores in the Himalayas (see section 5) we will focus on the vertical shear over the first of two domains, suggested by Wang and Fan [1999], which is best described by calculating $M$ over the region $5^{\circ}-20^{\circ} \mathrm{N}, 40^{\circ}-80^{\circ} \mathrm{E}$ (see solid box in Figure 5). The interannual variability of $M$ over this region is shown in Figure 6. The simulated monsoon index $M_{\text {sim }}$ is significantly correlated $(\mathrm{p}<0.05)$ with the index derived from reanalysis data $M_{\text {obs }}$ in both ECHAM T30 ( $\mathrm{r}=0.51,1950$ $1994)$ and $\mathrm{T} 106(\mathrm{r}=0.52,1979-1998)$. The T30 simulation, however, indicates that the ability of the ECHAM model to accurately reproduce the monsoon circulation undergoes significant decadal-scale variability. A sliding correlation between $M_{s i m}$ in the T30 version and $M_{\text {obs }}$, with a moving 15-year window (not shown), reveals a maximum correlation of $\mathrm{r}=0.75$ between 1968 and 1982, while it drops to a minimum of $r=0.26$ for the period $1979-1993$.

\section{Climatic Controls on Stable Isotopes}

[20] Stable isotopic variations recorded in paleoclimatic proxies are often interpreted in terms of local climate variations, such as temperature or precipitation amount [Dansgaard, 1964]. Although there is mounting evidence from model simulations [e.g., Hoffmann et al., 1998; Cole et al., 1999; Werner et al., 2001; Noone and Simmonds, 2002; Werner and Heimann, 2002; Vuille et al., 2003a; Yoshimura et al., 2003] that such interpretations can only partially explain the observed variability and that information about the transport and condensation history from source to deposition are equally important, it is worthwhile to first briefly consider the relationship between $\delta^{18} \mathrm{O}$ and local temperature and precipitation amount (section 4.1.). Since we are primarily interested in interannual variability of $\delta^{18} \mathrm{O}$, all results in this section are based on monthly anomalies, with the seasonal cycle removed. In a second step we will then also explore the influence of interannual variations in the large-scale monsoon circulation as defined above in more detail (section 4.2.).

\subsection{Local Controls: Temperature and Precipitation Amount}

[21] Figures $7 \mathrm{a}-7 \mathrm{c}$ show the temporal correlation of monthly anomalies between $\delta^{18} \mathrm{O}$ and air temperature. It is easily apparent from the pattern in Figure $7 \mathrm{a}$ that there is generally no significant temporal correlation between local air temperature and $\delta^{18} \mathrm{O}$ in precipitation in the Asian monsoon region. Only a few dispersed IAEA stations in the Middle East (Teheran and Ankara), southeast Asia (Singapore and Eastern Caroline Island), and in southwest Africa (Windhoek) show a significant correlation. The ECHAM model overestimates this relationship and produces significant correlations over much of the land areas, such as in tropical Africa, northern Australia and southeast Asia (Figures $7 \mathrm{~b}$ and $7 \mathrm{c}$ ). Over the Indian Ocean correlations are negative, which appears to be consistent with the very limited data from the IAEA network. This negative correlation is not physically meaningful and probably represents an artifact of the covariation of temperature with precipitation amount in these regions (see next section). In any case, the strength of the relationship again seems to be much stronger in the simulations than in reality. This apparent overestimation of the local climatic influence on $\delta^{18} \mathrm{O}$ is consistent with results by Hoffmann et al. [2005], who came to similar conclusion based on studies with the ECHAM-4 model.

[22] Figures $7 \mathrm{~d}-7 \mathrm{f}$ shows the same analysis but based on the correlation between anomalies in $\delta^{18} \mathrm{O}$ and local precipitation amount. Consistent with results from other parts of 

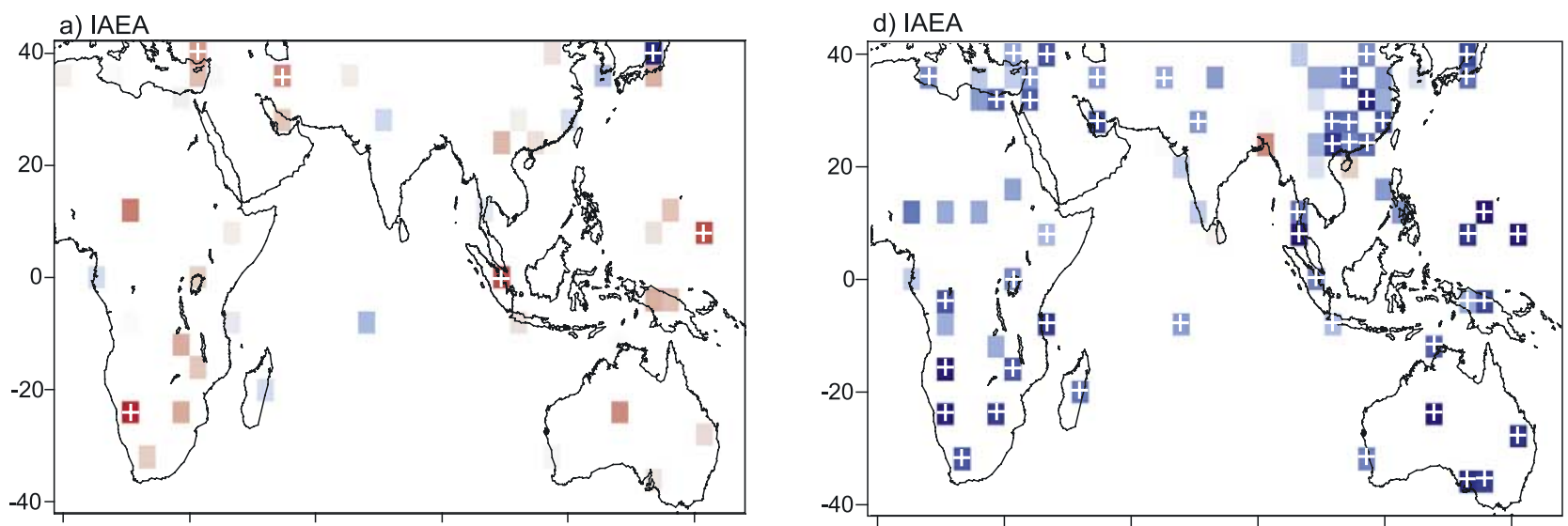

b) ECHAM-4 T106

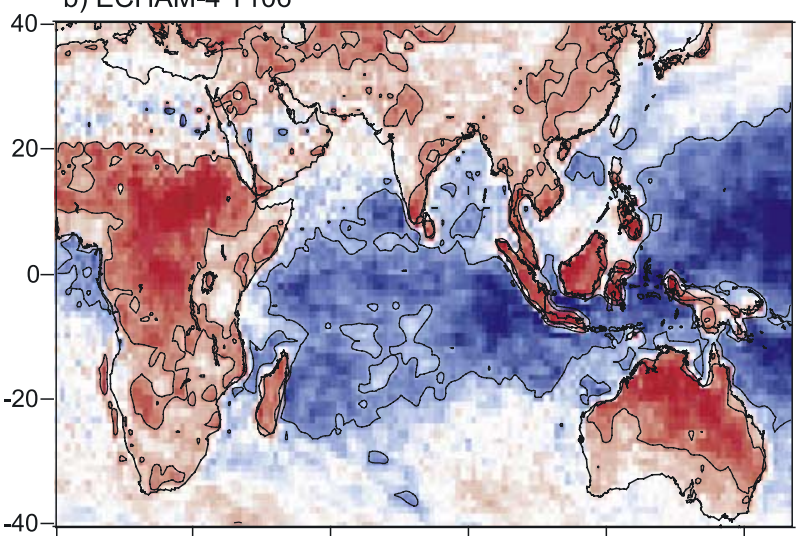

e) ECHAM-4 T106

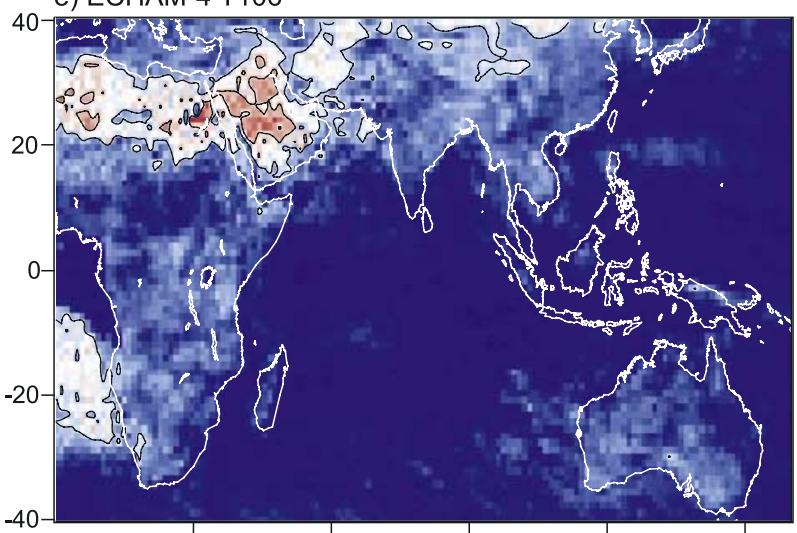

c) ECHAM-4 T30

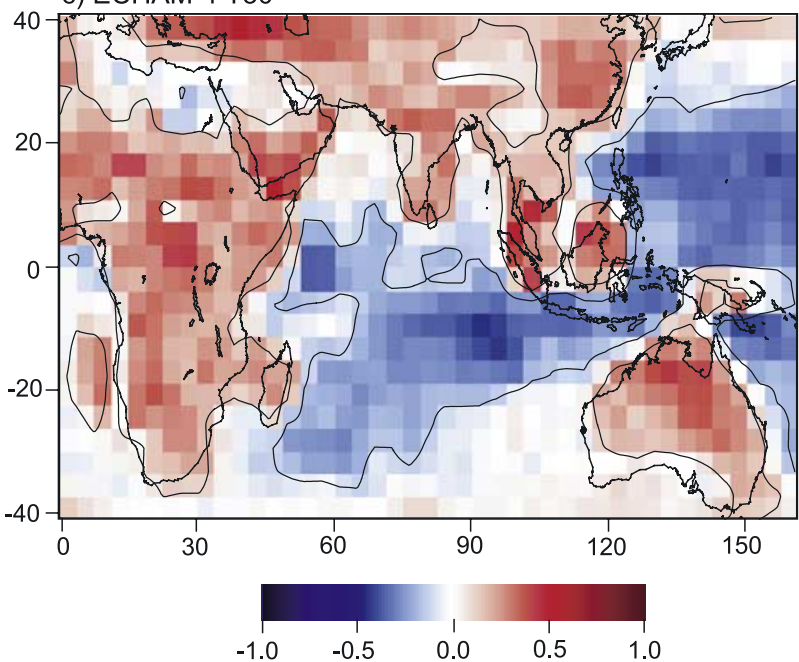

f) ECHAM-4 T30

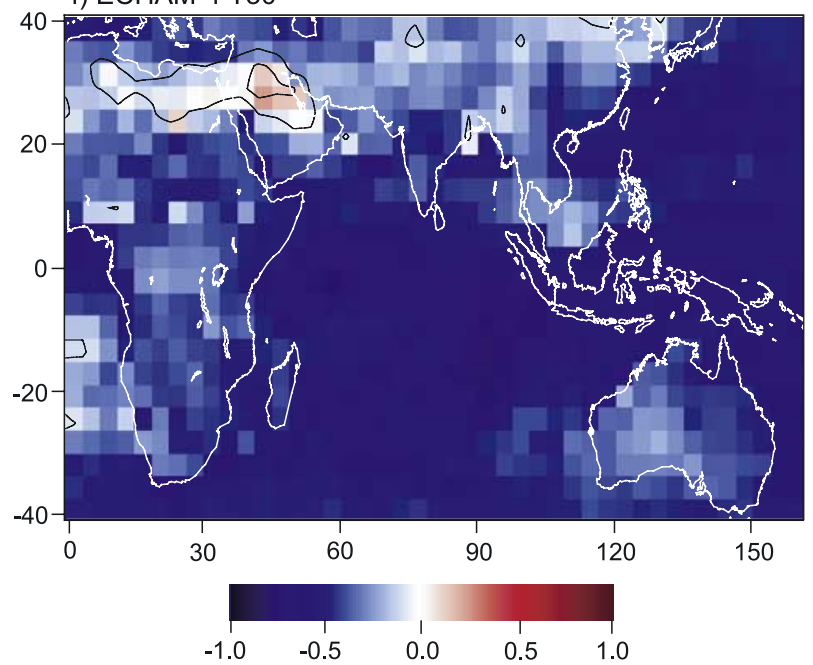

Figure 7. (a) Correlation between monthly anomalies of temperature and $\delta^{18} \mathrm{O}$ based on IAEA station data. Significant correlations at $p<0.05$ are indicated by white crosses. (b) As in Figure 7 a but for ECHAM-4 T106, with black contour line indicating regions where correlation is significant at $\mathrm{p}<0.05$. (c) As in Figure 7b but for ECHAM-4 T30. (d-f) As in Figures 7a-7c but for correlation between monthly anomalies of precipitation and $\delta^{18} \mathrm{O}$.

the tropics [Cole et al., 1999; Vuille et al., 2003a] correlations are negative almost everywhere, that is wet periods are characterized by more negative (depleted) $\delta^{18} \mathrm{O}$ values, while during dry phases the stable isotopic composition of precipitation is more positive (enriched). The significance of this relationship varies spatially, with significant correla- tions prevailing over all of Australia, the western tropical Pacific, southeast Asia, southern China, most of the Middle East and southern Africa (Figure 7d). All stations which showed a significant positive correlation with temperature (Figure 7a) are also significantly negatively correlated with precipitation amount. A much weaker and mostly insignif- 
a) IAEA

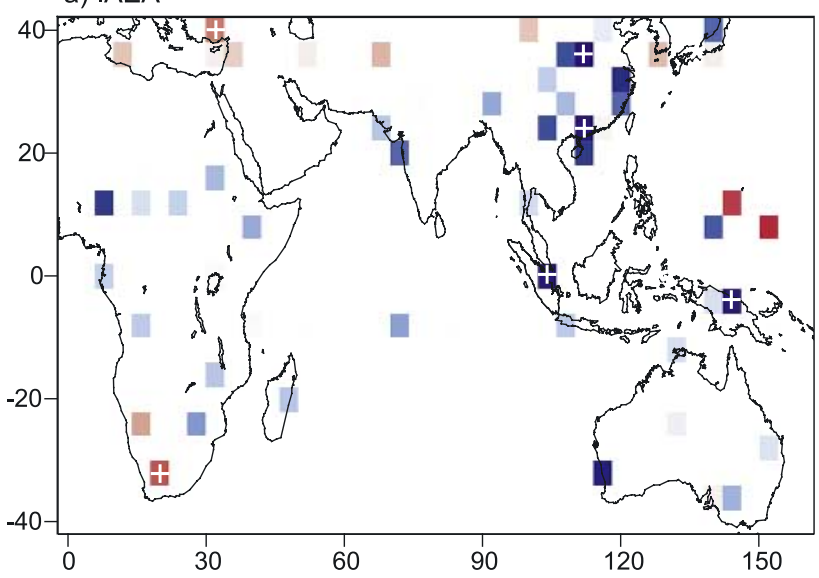

b) ECHAM-4 T106
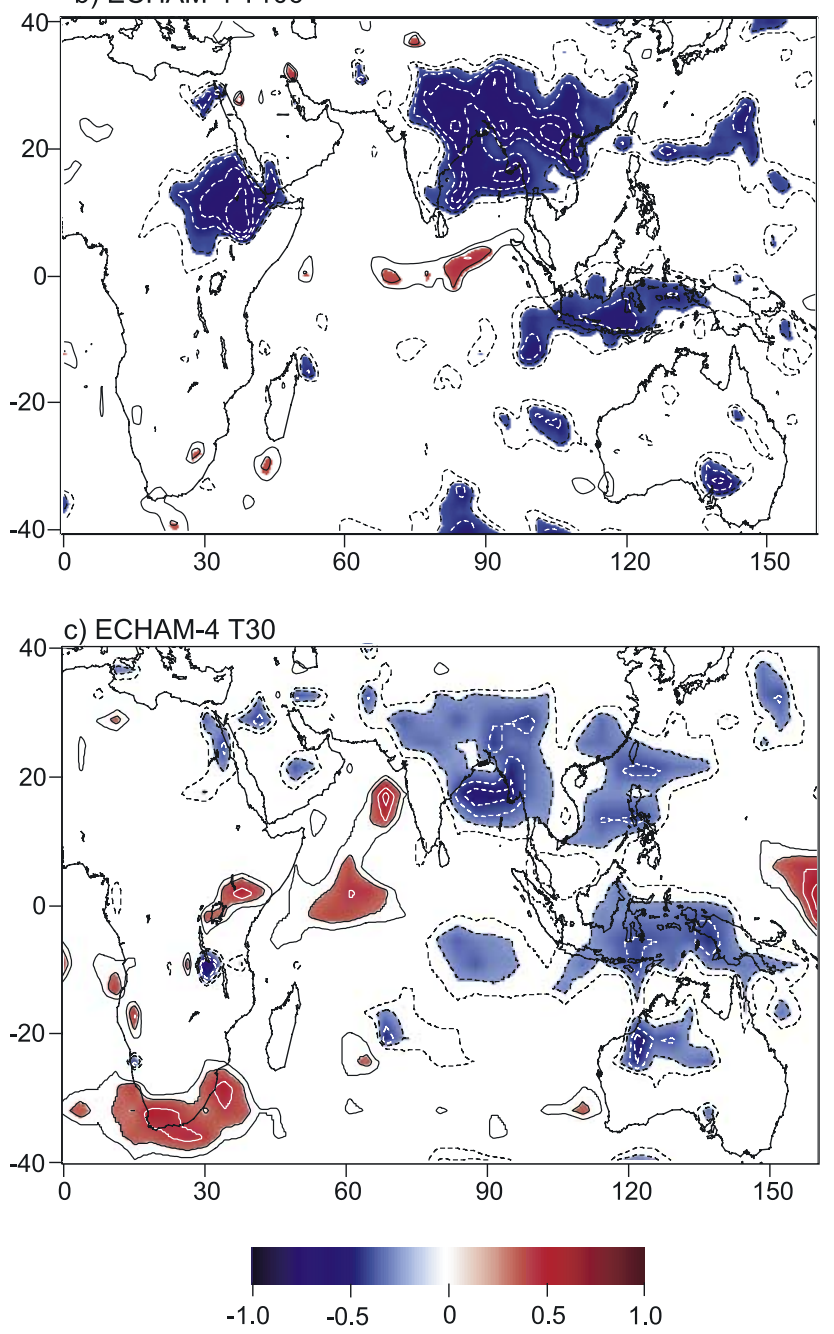

Figure 8. (a) Correlation of monsoon index $M$ with JJAS $\delta^{18} \mathrm{O}$ anomalies based on IAEA station data. Significant correlations at $\mathrm{p}<0.05$ are indicated by white crosses. (b) As in Figure 8a except for ECHAM-4 T106. Contour interval is 0.1 ; negative contours are dashed, and contours $-0.1,0$, and 0.1 are omitted. Regions where $\delta^{18} \mathrm{O}$ is significantly positively (negatively) correlated with $M$ are shaded in red (blue). (c) As in Figure 8b except for ECHAM-4 T30. icant relationship between precipitation amount and $\delta^{18} \mathrm{O}$ is apparent over the Sahel region, the west coast of India and interior China. The model quite accurately portrays this relationship and features significant negative correlations over most of the Asian monsoon domain. Exceptions include the dry regions of the Sahara and the northern Arabian Peninsula (Figures $7 \mathrm{e}$ and $7 \mathrm{f}$ ), consistent with results given by Hoffmann et al. [1998]. Overall the strong relationship between interannual variations in $\delta^{18} \mathrm{O}$ and precipitation amount seems to bolster the recent interpretation of $\delta^{18} \mathrm{O}$ as a recorder of wet or dry conditions in a number of proxies from this region [e.g., Burns et al., 2002; Kang et al., 2000; Qin et al., 2002; Fleitmann et al., 2003; Yadava and Ramesh, 2005]. It also shows that the lack of a significant spatial correlation between precipitation amount and $\delta^{18} \mathrm{O}$ [Aggarwal et al., 2004] should not be interpreted as evidence for the lack of such a relationship on an interannual temporal scale in most locations dominated by the Asian monsoon.

\subsection{Large-Scale Controls: Monsoon Circulation}

[23] To assess the impact of the large-scale monsoon circulation on $\delta^{18} \mathrm{O}$, we first correlate $M$ with both the observed and simulated stable isotopic composition of precipitation (Figure 8). The same monsoon index $M$ is then also correlated with OLR and simulated precipitation fields (Figure 9) to see whether the monsoon signal recorded in the stable isotopic composition can simply be interpreted as a response to changes in monsoon precipitation as suggested in Figures $7 d-7 f$, or whether other factors are at play.

[24] $\delta^{18} \mathrm{O}$ values are negatively correlated with monsoon strength over almost the entire Asian monsoon domain, indicating that the stable isotopic composition of precipitation is more depleted during intense monsoon seasons and more enriched during weak monsoons (Figure 8a). Notable exceptions to this rule occur along the border and outside the region of monsoon influence in southern Africa, the Mediterranean, interior Asia and the western tropical Pacific. While the spatial pattern of negative correlations is very coherent, the strength of the relationship at individual stations is rather weak and in most cases insignificant at the $95 \%$ level. This may partially be due to the rather short record length at many IAEA stations (the record length of the stations included in this analysis varies between 6 and 36 years). More likely, however, it reflects the nature of the monsoon index $M$, which is a good proxy for variations of the large-scale monsoon circulation, but not necessarily a good descriptor of precipitation variability at individual sites. The results based on the two ECHAM simulations are consistent with the evidence from the observational analysis and simulate a significant negative relationship between $M_{\text {sim }}$ and $\delta^{18} \mathrm{O}$ in the Bay of Bengal-IndiaHimalaya region extending eastward into China and also to the southeast over the maritime continent (Figures $8 \mathrm{~b}$ and 8c). Smaller regions of significant negative correlations are also apparent over parts of Australia, the eastern Indian Ocean and northern East Africa extending into the Arabian Peninsula. In the T30 simulation (Figure 8c) there are also regions, which experience significant positive correlations, such as southernmost Africa and the western equatorial Pacific, consistent with the IAEA data. 
a) OLR

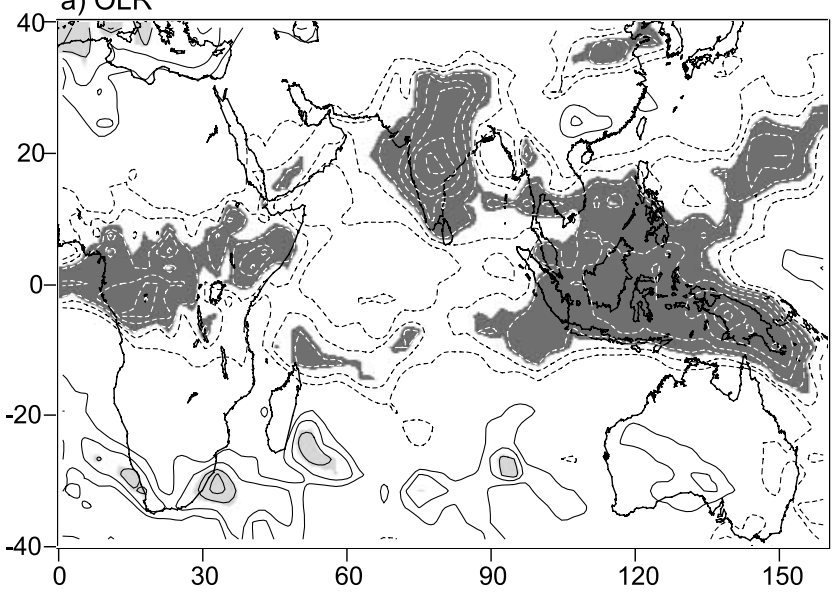

b) ECHAM-4 T106

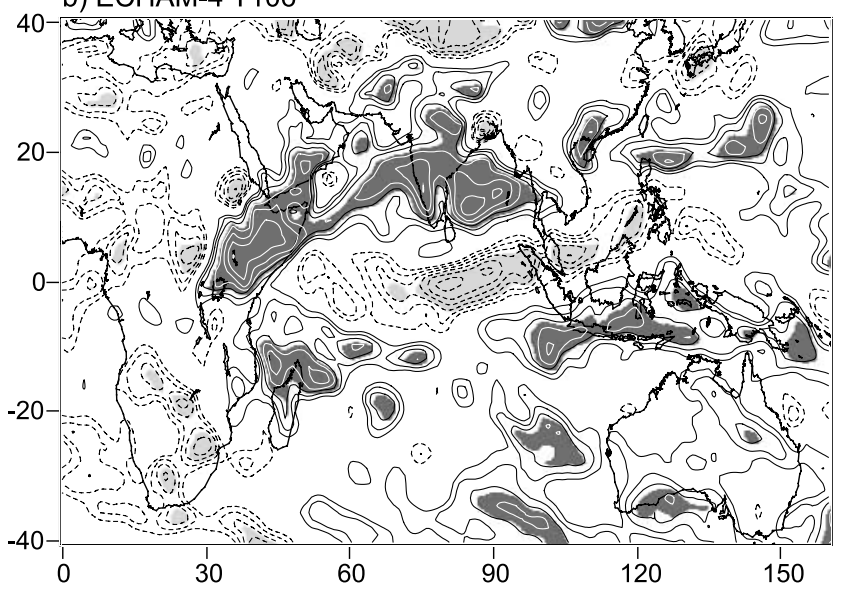

c) ECHAM-4 T30

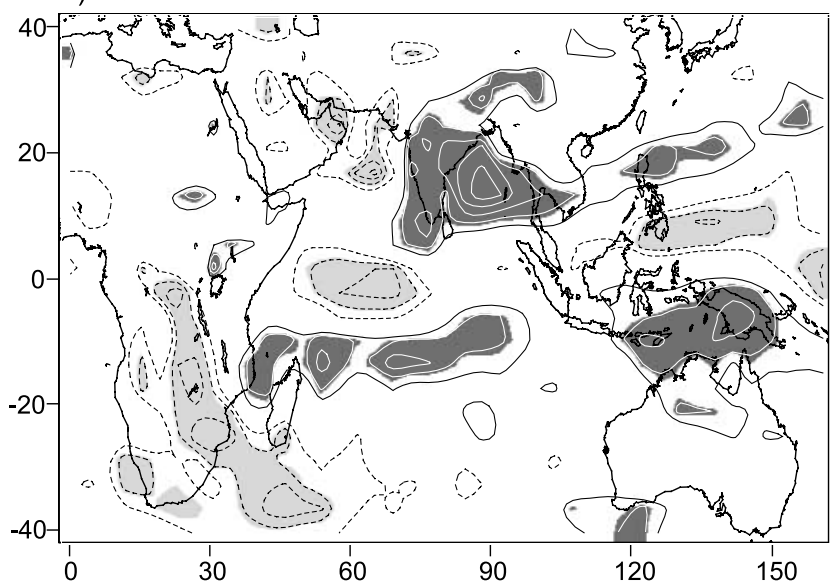

Figure 9. (a) Correlation of monsoon index $M$ with JJAS OLR (1974-1998). Contour interval is 0.1 ; negative contours are dashed, and contours $-0.1,0$, and 0.1 are omitted. Regions where OLR is significantly $(\mathrm{p}<0.05)$ positively (negatively) correlated with $M$ are indicated by light (dark) shading. (b) As in Figure 9a except for ECHAM-4 T106 and for correlation with precipitation. (c) As in Figure 9b except for ECHAM-4 T30. Please note that shading is reversed in Figures $9 \mathrm{~b}$ and $9 \mathrm{c}$ because of the inverse relationship between precipitation and OLR.
[25] In both observations and the ECHAM simulations the correlation field between $M$ and $\delta^{18} \mathrm{O}$ is the reversed image of the correlation between $M$ and OLR or precipitation (Figure 9). An intensified Asian summer monsoon is characterized by enhanced convective activity extending from equatorial Africa over southernmost Arabia, the Indian subcontinent and the Himalayas, all the way toward southeast Asia (Figure 9a). These are the same regions, where the correlation between $M$ and $\delta^{18} \mathrm{O}$ is negative (Figure 8a). Conversely, the regions bordering the Asian monsoon domain where the correlation between $M$ and $\delta^{18} \mathrm{O}$ is positive (southern Africa, the Mediterranean, the western equatorial Pacific) also show reduced convective activity during strong monsoon seasons. The close resemblance of the two correlation fields $M-\delta^{18} \mathrm{O}$ and $M-$ OLR is a strong argument for a significant first-order influence of the precipitation amount on $\delta^{18} \mathrm{O}$ as described in Figures $7 \mathrm{~d}-7 \mathrm{f}$. Clearly $\delta^{18} \mathrm{O}$ is more negative in those regions where an intensified monsoon translates into enhanced convective activity and precipitation. Conversely where a weakened monsoon leads to reduced convection, more positive $\delta^{18} \mathrm{O}$ values prevail.

[26] The ECHAM model shows similar characteristics (Figures $9 \mathrm{~b}$ and $9 \mathrm{c}$ ), with significant positive correlations between $M_{\text {sim }}$ and precipitation over southeast Asia, the Indian subcontinent including the Himalayas and the Bay of Bengal, East Africa and southern Arabia (evident in the T106 simulation only). However, the correlations are generally less significant than in the observations. Indeed there are extended regions where $M_{\text {sim }}$ is significantly correlated with $\delta^{18} \mathrm{O}$ but not with the precipitation amount (e.g., over much of interior China). This shows that factors other than the often-invoked "amount effect" may be more important in these regions to explain $\delta^{18} \mathrm{O}$ variability. Most likely this negative correlation between $M$ and $\delta^{18} \mathrm{O}$ reflects the more intense rainout upstream during stronger monsoon summers, which leads to a more depleted $\delta^{18} \mathrm{O}$ content of the remaining water vapor. As a result $\delta^{18} \mathrm{O}$ of precipitation in interior Asia will be more negative, even if local precipitation amounts are not any higher than during normal or weak monsoon seasons. Hence, in many instances a more comprehensive view, interpreting the stable isotopic composition as an integrator of monsoon circulation strength, rather than simply as a proxy for rainfall amount, may be more appropriate.

[27] Finally there are also some regions where the model produced more enriched $\delta^{18} \mathrm{O}$ values during strong monsoons, in particular over the equatorial Indian Ocean (Figures $8 \mathrm{~b}$ and $8 \mathrm{c}$ ). Here convective activity and precipitation are significantly subdued during strong monsoon years in both observations (Figure 9a) and models (Figures 9b and $9 \mathrm{c})$. The anomalous subsidence in this region is the result of interactions between a planetary-scale Walker circulation with an anomalous regional-scale Hadley cell, sometimes termed the transverse and lateral monsoons [Webster et al., 1998]. These monsoon-related precipitation anomalies translate into more enriched $\delta^{18} \mathrm{O}$ in the ECHAM model (Figures $8 \mathrm{~b}$ and $8 \mathrm{c}$ ), but unfortunately no IAEA observations are available from this region to confirm those results.

\section{Monsoon Signal in Dasuopu $\delta^{18} \mathrm{O}$}

[28] The Himalayas and southern Tibet are one of the regions were both ECHAM simulations show a significant 

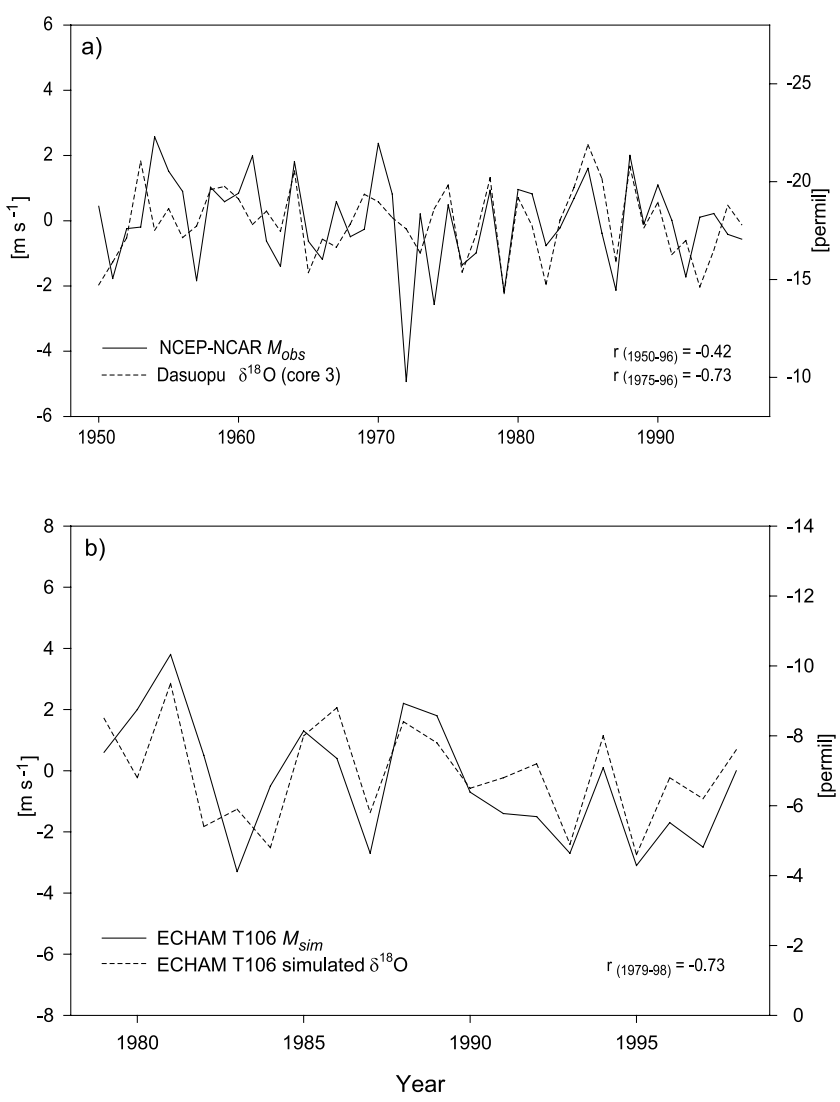

Figure 10. (a) Correlation of NCEP-NCAR JJAS monsoon index $M_{o b s}$ with annual $\delta^{18} \mathrm{O}$ values from Dasuopu ice core (core 3) between 1950 and 1996. (b) As in Figure 10a but for $M_{\text {sim }}$ and $\delta^{18} \mathrm{O}$ simulated from the grid cell closest to Dasuopu with ECHAM-4 T106 (1979-1998).

negative relationship between monsoon intensity $M$ and $\delta^{18} \mathrm{O}$ (Figures $8 \mathrm{~b}$ and $8 \mathrm{c}$ ). At the same time it is also a location from which a number of high-resolution stable isotopic proxy records are available. It is therefore in order to investigate how the $\delta^{18} \mathrm{O}$ records preserved in this region relate to the large-scale circulation and whether or not they are indeed faithful recorders of the Asian monsoon. We make use of an ice core record from Dasuopu $\left(28^{\circ} 23^{\prime} \mathrm{N}\right.$, $85^{\circ} 43^{\prime} \mathrm{E}, 7200 \mathrm{~m}$ a.s.1.) in the Himalayas [Thompson et al., 2000]. We use the annual $\delta^{18} \mathrm{O}$ values from core $\mathrm{C} 3$ between 1950 and 1996 and interpret them as representative of the summer monsoon season (JJAS). According to Davis and Thompson [2004] over $70 \%$ of the annual accumulation occurs during the summer monsoon and therefore annual $\delta^{18} \mathrm{O}$ essentially represents monsoon season $\delta^{18} \mathrm{O}$ (the two are correlated at $\mathrm{r}^{2}=0.90$ between 1949 and 1996). In addition we extract the simulated JJAS $\delta^{18} \mathrm{O}$ values in the ECHAM-4 T106 model from the grid cell located closest to Dasuopu for comparison with the actual ice core record. Figure 10 shows the time series of $\delta^{18} \mathrm{O}$ averaged over the monsoon season JJAS in both observations and the ECHAM-4 T106 simulation. In both cases the $\delta^{18} \mathrm{O}$ record is significantly negatively correlated with the respective monsoon index $M$. However, it is important to note, that the simulated $\delta^{18} \mathrm{O}$ from Dasuopu is not significantly correlated with the actual ice core $\delta^{18} \mathrm{O}$ record $(\mathrm{r}=0.22)$.
This indicates that the simulated $M-\delta^{18} \mathrm{O}$ relationship is internally consistent within the model, but that the model is not able to correctly reproduce interannual $\delta^{18} \mathrm{O}$ variability in the Himalayas. This is not surprising since the model simulated a monsoon index that correlated only at $r=0.52$ with the observed monsoon (Figure 6b). Clearly this discrepancy in the wind field has implications for the accurate simulation of the stable isotopic tracers in the model. In addition, our results confirm earlier studies, which show that global SST fields, which provide the only transient forcing in the model, are important but not sufficient to accurately simulate interannual monsoon variability. Nonetheless the close correlation between $\delta^{18} \mathrm{O}$ and $M$ in both observations and model allows for a more detailed analysis of their relationship.

[29] We limit our model analysis to the high-resolution T106 version of the ECHAM model and the last 2 decades. The T30 simulation is too coarse to resolve the topography of the Himalayas and Tibet reasonably well. Furthermore the observed breakdown between $\delta^{18} \mathrm{O}$ and $M$ in the mid1970s (Figure 10a) makes a comparison between model and observational results pre-1970 rather problematic. This breakdown could be due to a number of reasons, including a dating problem of the ice core. While we have no basis to argue that this is indeed the case, a one year offset of the ice core record would already be sufficient to cause a complete breakdown of the relationship between $\delta^{18} \mathrm{O}$ and related climate variables, given the biennial character of the Asian monsoon. Even when using the data from the T106 simulation, we do not suggest that the respective grid cell in the model is similar to the ice core location. We picked this grid cell because it is representative of the simulated climate and stable isotopic composition of southern Tibet and the Himalaya and therefore can help identify processes associated with monsoon and $\delta^{18} \mathrm{O}$ variability. In addition we only compare interannual variations between model and grid cell and not actual values.

[30] Figure 11 shows the Dasuopu $\delta^{18} \mathrm{O}$ record regressed against OLR, precipitation, and $250 \mathrm{hPa}$ divergent circulation (divergent wind and velocity potential), based on both the ice core $\delta^{18} \mathrm{O}$ (Figures 11a and 11c) and the simulated $\delta^{18} \mathrm{O}$ (Figures $11 \mathrm{~b}$ and $11 \mathrm{~d}$ ). Hence the figures portray atmospheric circulation anomalies associated with anomalously enriched $\delta^{18} \mathrm{O}$. The negative association between monsoon intensity and Dasuopu $\delta^{18} \mathrm{O}$ is therefore stronger, the closer the regression fields correspond with circulation anomalies known to occur during weak monsoon summers. As this is a linear analysis, the circulation anomalies associated with summers when $\delta^{18} \mathrm{O}$ is below average, would be reversed. We consider the divergent circulation as this component is more directly linked to monsoon precipitation, gives a better representation of the anomalous large-scale overturning circulation associated with the Asian monsoon, and allows for an easier depiction of the centers of large-scale convergence and divergence [e.g., Trenberth et al., 2000]. The OLR and precipitation fields (Figures 11c and 11d) indicate subdued convection over the maritime continent and the Indian subcontinent including the Himalayas at times when $\delta^{18} \mathrm{O}$ in the Dasuopu ice core is more enriched and strongly resemble the anomalous convection and precipitation associated with variations in monsoon strength (see Figure 9). The ECHAM simulation also 
a) Dasuopu $\delta^{18} \mathrm{O}$ vs. JJAS $250 \mathrm{hPa} u_{d i v}, v_{d i v}, \chi$

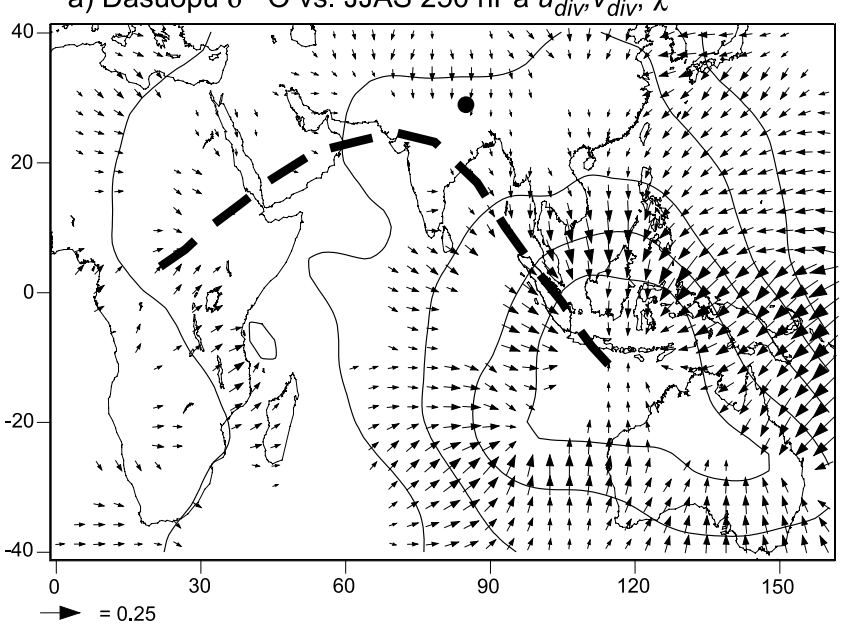

c) Dasuopu $\delta^{18} \mathrm{O}$ vs. JJAS OLR

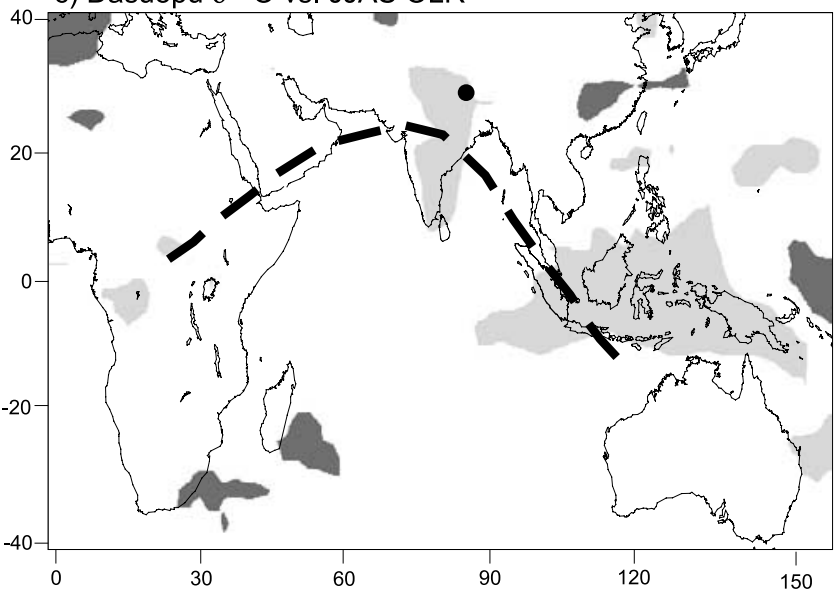

b) ECHAM-4 T106 $\delta^{18} \mathrm{O}$ vs. JJAS $250 \mathrm{hPa} u_{\text {div }}, v_{\text {div }}, \chi$

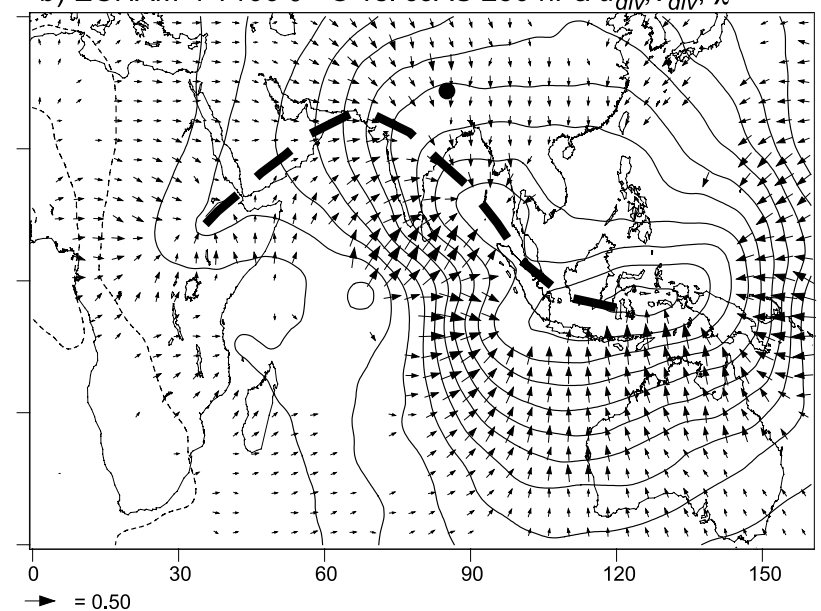

d) ECHAM-4 T106 $\delta^{18} \mathrm{O}$ vs. JJAS P

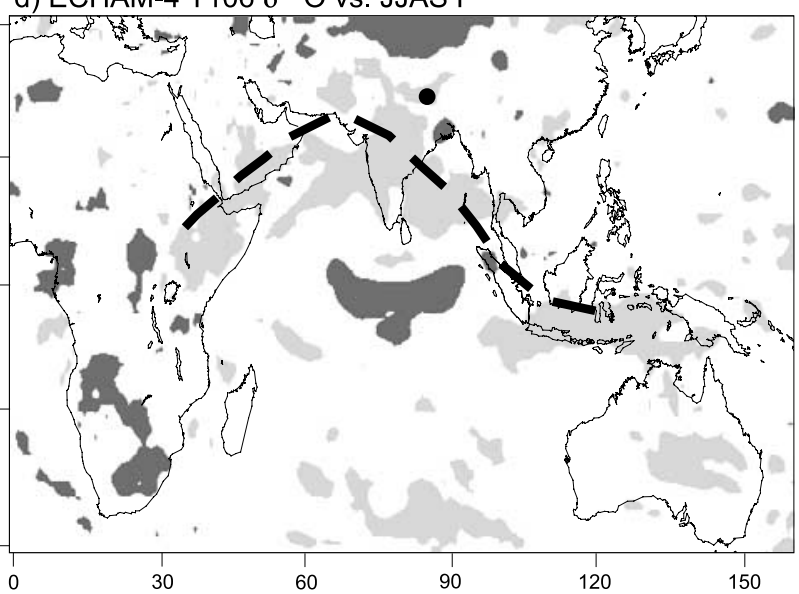

Figure 11. (a) Dasuopu $\delta^{18} \mathrm{O}$ (core 3 ) regressed against JJAS NCEP-NCAR $250 \mathrm{hPa}$ velocity potential $(\chi)$ and divergent wind $\left(\mathrm{u}_{\mathrm{div}}, \mathrm{v}_{\mathrm{div}}\right)$ between 1975 and 1996. Wind vectors are only shown where either zonal or meridional divergent wind component are significantly correlated $(\mathrm{p}<0.05)$ with Dasuopu $\delta^{18} \mathrm{O}$. Scale for divergent wind vector $\left(\mathrm{m} \mathrm{s}^{-1}\right.$ per stdev.) is shown at the bottom left. Contour interval for velocity potential is $10^{5} \mathrm{~m}^{2} \mathrm{~s}^{-1}$ per stdev.; 0 -contour is omitted, and negative contours are dashed. (b) As in Figure 11a except for ECHAM-4 T106 between 1979 and 1998. (c) As in Figure 11a except for OLR. Light (dark) shading indicates regions where OLR is significantly $(\mathrm{p}<0.05)$ positively (negatively) correlated with Dasuopu $\delta^{18} \mathrm{O}$. (d) As in Figure 11c except for ECHAM-4 T106 between 1979 and 1998 and with precipitation instead of OLR. Light (dark) shading indicates regions where P is significantly $(p<0.05)$ negatively (positively) correlated with Dasuopu $\delta^{18} \mathrm{O}$. Bold dashed line indicates zone of maximum anomalous upper tropospheric convergence. Solid dots indicate location of Dasuopu.

portrays a connection between Dasuopu $\delta^{18} \mathrm{O}$ and the convective dipole between the Indian subcontinent and the equatorial Indian Ocean (Figure 11d), often related to adjustments in the anomalous local Hadley circulation [Goswami et al., 1999; Lau and Wu, 2001]. In the observational record (Figure 11c) however, such a connection is not apparent. The anomalous centers of upper tropospheric convergence and low-level divergence (not shown) are in excellent agreement with these regions of reduced OLR during periods of enriched Dasuopu $\delta^{18} \mathrm{O}$. Such years are characterized by anomalous low-level divergence and upper level convergence extending from the center over the maritime continent toward India and the Himalayas and then southwestward toward Arabia and the Horn of Africa (thick dashed line). The implied anomalous descent over the maritime continent extending northwestward into the Asian continent is consistent with the longitudinal shift of the Walker circulation during weak monsoon years and can also be observed on intraseasonal timescales associated with active and break phases of the Asian monsoon [Webster et al., 1998]. Hence these results further bolster the argument that Dasuopu $\delta^{18} \mathrm{O}$ does indeed record anomalous monsoon circulation. The divergent low-level outflow over the maritime continent with anomalous westerlies over the western tropical Pacific and easterlies over the western Indian Ocean (not shown) is also a typical feature of the eastward shifted Walker circulation and often observed during El Niño episodes. This is consistent with recent results by Bradley 
et al. [2003], who showed that the $\delta^{18} \mathrm{O}$ record from Dasuopu is significantly positively correlated with tropical Pacific SSTA.

[31] In the past the ice core record from Dasuopu has been interpreted in a number of different ways. The main controversy surrounding this record is whether the climatic controls on the $\delta^{18} \mathrm{O}$ record vary depending on the timescale considered. $\delta^{18} \mathrm{O}$ in the ice core is significantly more depleted during the summer monsoon season than during the cold winter, and there is general agreement that this phenomenon is a result of intense summer monsoon precipitation. However, it has been suggested, that on longer timescales the $\delta^{18} \mathrm{O}$ record from Dasuopu is a proxy for temperature and that the observed isotopic enrichment in the top part of the core is reflecting rising temperatures [e.g., Thompson et al., 2000; Yao et al., 2002; Davis et al., 2005]. Davis and Thompson [2004] showed that there is little correspondence $\left(\mathrm{r}^{2}=-0.09,1949-1996\right)$ between annual net accumulation and $\delta^{18} \mathrm{O}$ and therefore refuted the possibility of an "amount effect." On the other hand Kang et al. [2000] and Tian et al. [2003] did find such a relationship between $\delta^{18} \mathrm{O}$ and precipitation in the Dasuopu record when comparing $\delta^{18} \mathrm{O}$ with precipitation amount from a nearby station rather than the ice core accumulation itself. This raises the question whether net snow accumulation adequately represents annual total accumulation, a problem also observed at other tropical drill sites [Hardy et al., 2003]. Maybe more importantly however, as documented in Figures 8 and 9, variations in monsoon intensity can have a significant impact on $\delta^{18} \mathrm{O}$ in this region without drastic changes in the local amount of precipitation. It is not necessary to invoke an "amount effect" in order to establish a link between the $\delta^{18} \mathrm{O}$ composition in the Himalayas and monsoon strength. Our results suggest that the Dasuopu site is indeed very sensitive to fluctuations in Asian monsoon intensity. Over the most recent time period variations in monsoon strength explain more than $50 \%$ of the Dasuopu ice core $\delta^{18} \mathrm{O}(\mathrm{r}=-0.73,1975-1996$, Figure 10a), a result faithfully reproduced in the ECHAM T106 simulation (Figure 10b). Our results are also supported by a number of recent studies linking the stable isotopic composition of precipitation derived from Tibetan ice cores, snow pit studies, and precipitation sampling programs in the Himalayas with the Asian monsoon and with moisture flux from the Indian and Pacific oceans [e.g., Araguas-Araguas et al., 1998; Kang et al., 2000, 2002; Tian et al., 2001, 2003; Qin et al., 2002; Johnson and Ingram, 2004].

\section{Summary and Conclusion}

[32] On the basis of two different simulations with the ECHAM-4 model, we investigate the present-day relationship between the stable isotopic composition of precipitation $\left(\delta^{18} \mathrm{O}\right)$ and the Asian monsoon. A model evaluation of several relevant parameters shows that the model has some deficiencies when simulating interannual variations of monsoon precipitation, but that the associated large-scale circulation is much more faithfully reproduced. The associated stable isotopic fields are quite similar to the observations, although an in-depth comparison is not possible because of the lack of a long and dense observational network.
[33] The local climatic controls are overestimated by the model; in particular the impact of local temperature on $\delta^{18} \mathrm{O}$ is much stronger in the model than in reality. The simulated impact of the precipitation amount is also very significant, but unlike for temperature this is supported by observations over most regions. The large-scale influence of the Asian monsoon on $\delta^{18} \mathrm{O}$ is considered by creating an index of vertical shear $M$, which is proportional in strength to the latent heat, released during monsoon precipitation. The ECHAM model shows a significant relationship between the $\delta^{18} \mathrm{O}$ composition of precipitation and $M$, extending in an arch from southeast Asia northwestward to the Indian subcontinent and the Himalayas and then southwestward to the Arabian Peninsula and the Horn of Africa. The limited data from the IAEA-GNIP database are consistent with these results and indicate more depleted $\delta^{18} \mathrm{O}$ values in those regions during intense monsoon seasons. While the amount of precipitation is important and provides a firstorder explanation for the observed monsoon- $\delta{ }^{18} \mathrm{O}$ relationship in many regions, the ECHAM results suggest that a significant relationship may also occur in areas where precipitation is not significantly affected by monsoon variability. In these regions, e.g., interior China, the monsoon $\delta^{18} \mathrm{O}$ relationship is probably a result of distillation processes during transport and hence increased rainout and depletion of heavy isotopes upstream.

[34] In summary our results suggest that traditional interpretations of $\delta^{18} \mathrm{O}$ as recorders of local climatic conditions such as temperature or precipitation amount may not be adequate in some regions affected by the Asian monsoon. This is particularly the case where there may be competing effects between the two variables, which are often virtually impossible to disentangle. Since $\delta^{18} \mathrm{O}$ is ultimately a recorder of atmospheric circulation, integrating all aspects of atmospheric transport from source to sink, it may be more appropriate to simply view $\delta^{18} \mathrm{O}$ as a proxy for monsoon circulation. Our index $M$ is one choice for such an index, and its close correspondence with the $\delta^{18} \mathrm{O}$ from Dasuopu in both observations and model suggests that it may indeed represent many aspects of climate and atmospheric circulation that affect the $\delta^{18} \mathrm{O}$ composition in the Asian monsoon domain. Whether such a relationship between variations in Dasuopu $\delta^{18} \mathrm{O}$ and changes in the Asian monsoon also holds on longer timescales or under changed boundary conditions, however, is not clear and beyond the scope of this study. Future studies will focus on these questions by employing AGCMs fitted with stable isotopic tracers and forced with mid-Holocene and Last Glacial Maximum boundary conditions.

[35] Acknowledgments. NCEP-NCAR reanalysis, OLR and CMAP precipitation data were obtained from the NOAA CIRES Climate Diagnostics Center. $\delta^{18} \mathrm{O}$ data from the Dasuopu ice core were kindly provided by Lonnie G. Thompson. ECHAM simulations were performed with support of the German Climate Computing Center (DKRZ) in Hamburg, Germany. We are grateful for the insightful comments of three anonymous reviewers, which helped to considerably improve the quality of this manuscript. This study was funded by the National Science Foundation (ATM-0317693) and NOAA Office of Global Programs (NA03OAR4310046).

\section{References}

Aggarwal, P. K., K. Froehlich, K. M. Kulkarni, and L. L. Gourcy (2004), Stable isotope evidence for moisture sources in the Asian summer monsoon under present and past climate regimes, Geophys. Res. Lett., 31, L08203, doi:10.1029/2004GL019911. 
Araguas-Araguas, L., K. Froehlich, and K. Rozanski (1998), Stable isotope composition of precipitation over southeast Asia, J. Geophys. Res. 103(D22), 28,721-28,742

Bamzai, A. S., and J. Shukla (1999), Relation between Eurasian snow cover, snow depth, and the Indian summer monsoon: An observational study, J. Clim., 12, 3117-3132.

Bhattacharya, S. K., K. Froehlich, P. K. Aggarwal, and K. M. Kulkarni (2003), Isotopic variations in Indian Monsoon precipitation: Records from Bombay and New Delhi, Geophys. Res. Lett., 30(24), 2285, doi:10.1029/2003GL018453.

Bradley, R. S., M. Vuille, D. R. Hardy, and L. G. Thompson (2003), Low latitude ice cores record Pacific sea surface temperatures, Geophys. Res Lett., 30(4), 1174, doi:10.1029/2002GL016546.

Burns, S. J., D. Fleitmann, M. Mudelsee, U. Neff, A. Matter, and A. Mangini (2002), A 780-year annually resolved record of Indian Ocean monsoon precipitation from a speleothem from south Oman, J. Geophys. Res., 107(D20), 4434, doi:10.1029/2001JD001281.

Cherchi, A., and A. Navarra (2003), Reproducibility and predictability of the Asian summer monsoon in the ECHAM4-GCM, Clim. Dyn., 20 , $365-379$

Cole, J. E., D. Rind, R. S. Webb, J. Jouzel, and R. Healy (1999), Climatic controls on interannual variability of precipitation $\delta^{18} \mathrm{O}$ : Simulated influence of temperature, precipitation amount, and vapor source region, J. Geophys. Res., 104(D12), 14,223-14,235.

Dansgaard, W. (1964), Stable isotopes in precipitation, Tellus, 16, 436468

Davis, M. E., and L. G. Thompson (2004), Four centuries of climatic variation across the Tibetan plateau from ice core accumulation and $\delta^{18} \mathrm{O}$ records, in Earth Paleoenvironments: Records Preserved in Midand Low-Latitude Glaciers, edited by L. D. Cecil, J. R. Green, and L. G. Thompson, pp. 145-161, Springer, New York.

Davis, M. E., L. G. Thompson, T. Yao, and N. Wang (2005), Forcing of the Asian monsoon on the Tibetan Plateau: Evidence from high-resolution ice core and tropical coral records, J. Geophys. Res., 110, D04101, doi:10.1029/2004JD004933.

Duan, K., T. Yao, and L. G. Thompson (2004), Low-frequency of southern Asian monsoon variability using a 295-year record from the Dasuopu ice core in the central Himalayas, Geophys. Res. Lett., 31, L16209, doi:10.1029/2004GL020015.

Feng, X., H. Cui, K. Tang, and L. E. Conkey (1999), Tree-ring $\delta$ D as an indicator of Asian monsoon intensity, Quat. Res., 51, 262-266.

Fleitmann, D., S. J. Burns, M. Mudelsee, U. Neff, J. Kramers, A. Mangini, and A. Matter (2003), Holocene forcing of the Indian Monsoon recorded in a stalagmite from southern Oman, Science, 300, 1737-1739.

Gadgil, S., and S. Sajani (1998), Monsoon precipitation in the AMIP runs, Clim. Dyn., 14, 659-689.

Gill, A. E. (1980), Some simple solutions for heat-induced tropical circulation, Q. J. R. Meteorol. Soc., 106, 447-462.

Goswami, B. N. (2000), Comments on "Choice of South Asian summer monsoon indices", Bull. Am. Meteorol. Soc., 81(4), 821-822.

Goswami, B. N. (2004), Interdecadal change in potential predictability of the Indian summer monsoon, Geophys. Res. Lett., 31, L16208, doi:10.1029/2004GL020337.

Goswami, B. N., V. Krishnamurthy, and H. Annamalai (1999), A broadscale circulation index for the interannual variability of the Indian summer monsoon, Q. J. R. Meteorol. Soc., 125(554), 611-633.

Gupta, A. K., D. M. Anderson, and J. T. Overpeck (2003), Abrupt changes in the Asian southwest monsoon during the Holocene and their links to the North Atlantic Ocean, Nature, 421, 354-357.

Hardy, D. R., M. Vuille, and R. S. Bradley (2003), Variability of snow accumulation and isotopic composition on Nevado Sajama, Bolivia, J. Geophys. Res., 108(D22), 4693, doi:10.1029/2003JD003623.

Hoffmann, G., and M. Heimann (1997), Water isotope modeling in the Asian monsoon region, Quat. Int., 37, 115-128.

Hoffmann, G., M. Werner, and M. Heimann (1998), Water isotope module of the ECHAM atmospheric general circulation model: A study on timescales from days to several years, J. Geophys. Res., 103(D14), 16,87116,896 .

Hoffmann, G., M. Cuntz, J. Jouzel, and M. Werner (2005), How much climate information do water isotopes contain?, in Isotopes in the Water Cycle-Past, Present and Future of a Developing Science, pp. 303-320, Springer, New York.

International Atomic Energy Agency/World Meteorological Organization (2004), Global Network of Isotopes in Precipitation: The GNIP Database, http://isohis.iaea.org, Vienna.

Jha, B., T. N. Krishnamurti, and Z. Christides (2000), A note on horizontal resolution dependence for monsoon rainfall simulations, Meteorol. Atmos. Phys., 74, 11-17.

Johnson, K. R., and B. L. Ingram (2004), Spatial and temporal variability in the stable isotope systematics of modern precipitation in China: Implica- tions for paleoclimate reconstructions, Earth Planet. Sci. Lett., 220, 365377.

Ju, J., and J. Slingo (1995), The Asian summer monsoon and ENSO, Q. J. R. Meteorol. Soc., 121(525), 1133-1168.

Kalnay, E., et al. (1996), The NCEP/NCAR 40-year reanalysis project, Bull. Am. Meteorol. Soc., 77, 437-471.

Kang, S., C. Wake, Q. Dahe, P. A. Mayewski, and T. Yao (2000), Monsoon and dust signals recorded in Dasuopu glacier, Tibetan Plateau, J. Glaciol., 46(153), 222-226.

Kang, S., K. J. Kreutz, P. A. Mayewski, D. Qin, and T. Yao (2002), Stableisotopic composition of precipitation over the northern slope of the central Himalaya, J. Glaciol., 48(163), 519-526.

Kumar, K. K., B. Rajagopalan, and M. A. Cane (1999), On the weakening relationship between the Indian monsoon and ENSO, Science, 284, 2156-2159.

Lau, K.-M., and H. T. Wu (2001), Principal modes of rainfall-SST variability of the Asian summer monsoon: A reassessment of the monsoonENSO relationship, J. Clim., 14, 2880-2895.

Liebmann, B., and C. A. Smith (1996), Description of a complete (interpolated) outgoing longwave radiation dataset, Bull. Am. Meteorol. Soc., 77, 1275-1277.

Meehl, G. A. (1994), Influence of the land surface in the Asian summer monsoon: External conditions versus internal feedbacks, J. Clim., 7, $1033-1049$.

Meehl, G. A., and W. M. Washington (1993), South Asian summer monsoon variability in a model with doubled atmospheric carbon dioxide concentrations, Science, 260, 1101-1104.

Moron, V., A. Navarra, M. N. Ward, and E. Roeckner (1998), Skill and reproducibility of seasonal rainfall patterns in the tropics in ECHAM-4 GCM simulations with prescribed SST, Clim. Dyn., 14, 83-100.

Morrill, C., J. T. Overpeck, and J. E. Cole (2003), A synthesis of abrupt changes in the Asian summer monsoon since the last deglaciation, $\mathrm{Ho}$ locene, 13(4), 465-476.

Noone, D., and I. Simmonds (2002), Associations between $\delta^{18} \mathrm{O}$ of water and climate parameters in a simulation of atmospheric circulation for 1979-95, J. Clim., 15, 3150-3169.

Oelfke Clark, C., J. E. Cole, and P. J. Webster (2000), Indian Ocean SST and Indian summer rainfall: Predictive relationships and their decadal variability, J. Clim., 13, 2503-2519.

Overpeck, J., D. Anderson, S. Trumbore, and W. Prell (1996), The southwest Indian monsoon over the last 18,000 years, Clim. Dyn., 12, $213-$ 225

Qin, D., S. Hou, D. Zhang, J. Ren, S. Kang, P. A. Mayewski, and C. P. Wake (2002), Preliminary results from the chemical records of an $80.4 \mathrm{~m}$ ice core recovered from East Rongbuk Glacier, Qomolangma (Mount Everest), Himalaya, Ann. Glaciol., 35, 278-284.

Robock, A., M. Mu, K. Vinnikov, and D. Robinson (2003), Land surface conditions over Eurasia and Indian summer monsoon rainfall, J. Geophys. Res., 108(D4), 4131, doi:10.1029/2002JD002286.

Sperber, K. R., and T. N. Palmer (1996), Interannual tropical rainfall variability in general circulation model simulations associated with the Atmospheric Model Intercomparison Project, J. Clim., 9, 2727-2750.

Thompson, L. G., T. Yao, M. E. Davis, K. A. Henderson, E. MosleyThompson, P.-N. Lin, J. Beer, H.-A. Synal, J. Cole-Dai, and J. F. Bolzan (1997), Tropical climate instability: The last glacial cycle from a QinghaiTibetan Ice core, Science, 276, 1821-1825.

Thompson, L. G., T. Yao, E. Mosley-Thompson, M. E. Davis, K. A. Henderson, and P. N. Lin (2000), A high-resolution millenial record of south Asian monsoon from Himalayan ice cores, Science, 289, 1916-1919.

Tian, L., V. Masson-Delmotte, M. Stievenard, T. Yao, and J. Jouzel (2001), Tibetan plateau summer monsoon northward extent revealed by measurements of water stable isotopes, J. Geophys. Res., 106(D22), 28,08128,088 .

Tian, L., T. Yao, P. F. Schuster, J. W. C. White, K. Ichiyanagi, E. Pendall, J. Pu, and W. Yu (2003), Oxygen-18 concentrations in recent precipitation and ice cores on the Tibetan Plateau, J. Geophys. Res., 108(D9), 4293, doi:10.1029/2002JD002173.

Trenberth, K., D. P. Stepaniak, and J. M. Caron (2000), The global monsoon as seen through the divergent atmospheric circulation, J. Clim., 13, 3969-3993

Tschuck, P., P. Chauvin, B. Dong, and K. Arpe (2004), Impact of sea-surface-temperature anomalies in the equatorial Indian Ocean and western Pacific on the Asian summer monsoon in three general circulation models, Int. J. Climatol., 24, 181-191.

Vuille, M., R. S. Bradley, M. Werner, R. Healy, and F. Keimig (2003a), Modeling $\delta{ }^{18} \mathrm{O}$ in precipitation over the tropical Americas: 1. Interannual variability and climatic controls, J. Geophys. Res., 108(D6), 4174, doi:10.1029/2001JD002038.

Vuille, M., R. S. Bradley, R. Healy, M. Werner, D. R. Hardy, L. G. Thompson, and F. Keimig (2003b), Modeling $\delta^{18} \mathrm{O}$ in precipitation over 
the tropical Americas: 2. Simulation of the stable isotope signal in Andean ice cores, J. Geophys. Res., 108(D6), 4175, doi:10.1029/2001JD002039.

Wang, B., and Z. Fan (1999), Choice of south Asian summer monsoon indices, Bull. Am. Meteorol. Soc., 80(4), 629-638.

Wang, B., R. Wu, and K.-M. Lau (2001a), Interannual variability of the Asian summer monsoon: Contrasts between the Indian and the western north Pacific-east Asian monsoons, J. Clim., 14, 4073-4090.

Wang, Y. J., H. Cheng, R. L. Edwards, Z. S. An, J. Y. Wu, C.-C. Shen, and J. A. Dorale (2001b), A high-resolution absolute-dated late Pleistocene monsoon record from Hulu cave, China, Science, 294, 2345-2348.

Webster, P. J., and S. Yang (1992), Monsoon and ENSO: selective interactive systems, Quat. J. R. Meteorol. Soc., 118(507), 877-926.

Webster, P. J., V. O. Magana, T. N. Palmer, J. Shukla, R. A. Toma, I. Yanai, and T. Yasunari (1998), Monsoons: Processes, predictability, and the prospects for prediction, J. Geophys. Res., 103(C7), 14,45114,510 .

Werner, M., and M. Heimann (2002), Modeling interannual variability of water isotopes in Greenland and Antarctica, J. Geophys. Res., 107(D1), 4001, doi:10.1029/2001JD900253.

Werner, M., M. Heimann, and G. Hoffmann (2001), Isotopic composition and origin of polar precipitation in present and glacial climate simulations, Tellus, Ser. B, 53, 53-71.

Wu, R., and B. P. Kirtman (2004), Impacts of the Indian Ocean on the Indian summer monsoon-ENSO relationship, J. Clim., 17, 3037-3054.
Xie, P., and P. A. Arkin (1997), Global precipitation: A 17-year monthly analysis based on gauge observations, satellite estimates, and numerical model outputs, Bull. Am. Meteorol. Soc., 78, 2539-2558.

Yadava, M. G., and R. Ramesh (2005), Monsoon reconstruction from radiocarbon dated tropical Indian speleothems, Holocene, 15(1), 48-59.

Yao, T., K. Duan, N. Wang, J. Pu, S. Kang, X. Qin, and L. G. Thompson (2002), Temperature and methane changes over the past 1000 years recorded in Dasuopu glacier (central Himalaya) ice core, Ann. Glaciol., 35, $379-383$.

Yoshimura, K., T. Oki, N. Ohte, and S. Kanse (2003), A quantitative analysis of short-term ${ }^{18} \mathrm{O}$ variability with a Rayleigh-type isotope circulation model, J. Geophys. Res., 108(D20), 4647, doi:10.1029/ 2003JD003477.

Yuan, D., et al. (2004), Timing, duration and transitions of the last interglacial Asian monsoon, Science, 304, 575-578.

R. S. Bradley, F. Keimig, and M. Vuille, Climate System Research Center, Department of Geosciences, University of Massachusetts, 611 North Pleasant Street, Amherst, MA 01003-9297, USA. (mathias@geo. umass.edu)

M. Werner, Max-Planck-Institute for Biogeochemistry, D-07745 Jena, Germany. 